\title{
OPERATIONAL READINESS AND OPERATIONAL READINESS REVIEW PROGRAM PLAN
}
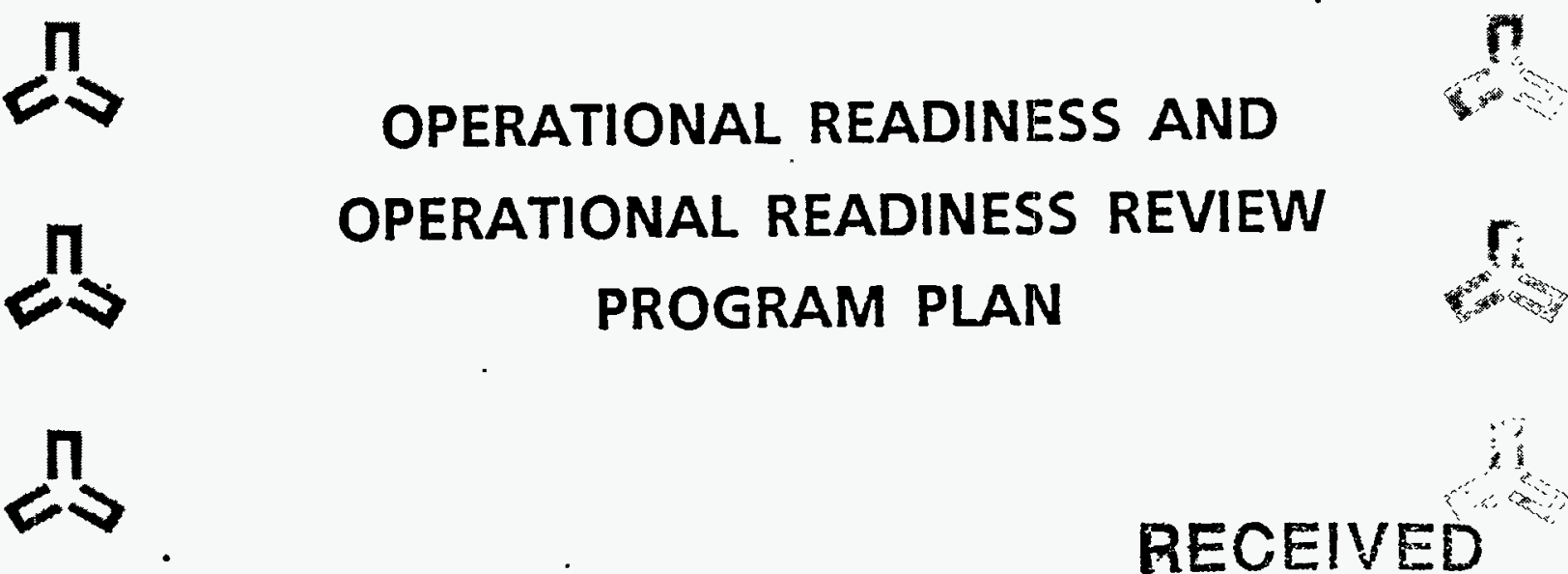

RECEIVED

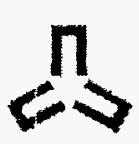

\section{October 1992}
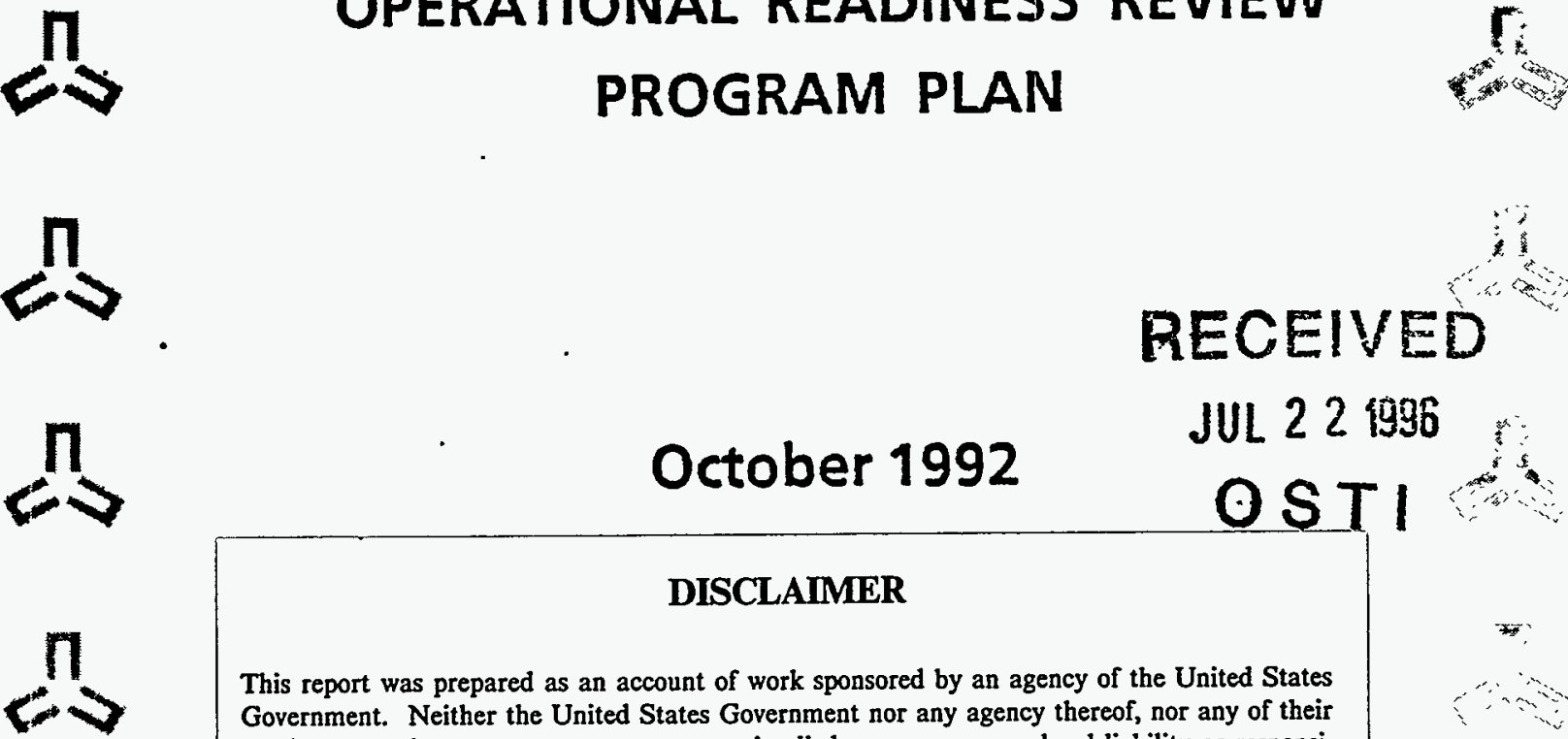

\section{DISCLAIMER}

This report was prepared as an account of work sponsored by an agency of the United States Government. Neither the United States Government nor any agency thereof, nor any of their employees, makes any warranty, express or implied, or assumes any legal liability or responsibility for the accuracy, completeness, or usefulness of any information, apparatus, product, or process disclosed, or represents that its use would not infringe privately owned rights. Reference herein to any specific commercial product, process, or service by trade name, trademark, manufacturer, or otherwise does not necessarily constitute or imply its endorsement, recommendation, or favoring by the United States Government or any agency thereof. The views and opinions of authors expressed herein do not necessarily state or reflect those of the United States Government or any agency thereof. 
EGEG NOUND APPITED TIECHNDIOEIES

OFGPAIIONAI RREDINESS ARD OFFRAIIONAI REPADINESS REVIEN PROGREM PIAN

I. OR/ORR Program Description

II. Contractor Operational Readiness Procedure

III. Contractor Operational Readiness Review \#1 Procedure

IV. Contractor Operational Readiness Review \#2 Procecture

Appendices
A. Bazard Class Detemination
B. References
C. Definitions and Acronyms
D. Conduct of Operations Self Assessment survey - Rev. 2
E. Checklist - Normal Safety Operation Readiness
F. ORRI Charter Exalle
G. Elements of an ORRI Plan

sukmitted by:

E. G. Depew

Manager, OR Implementation

Approved by:

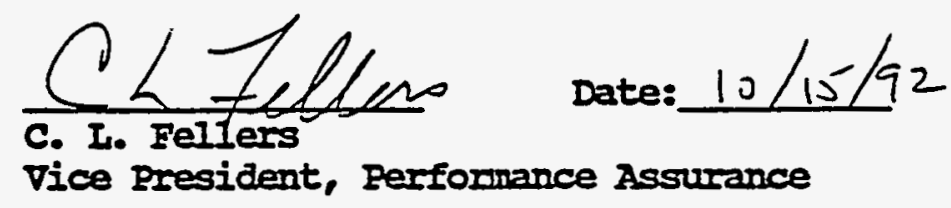




\section{DISCLAIMER}

Portions of this document may be illegible in electronic image products. Images are produced from the best available original document. 
SECIIION:

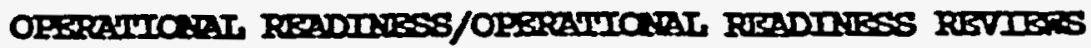

IIIIF:

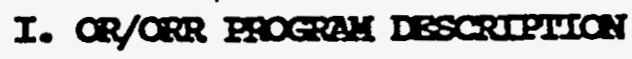

PURPOSE

The purpose of this program and set of procedures is to describe Koumd's plan to conduct and document operational Readiness (OR) and Operational Readiness Reviens (ORR).

The OR process provides a fomal, auditable methodology for obtaining operational readiness of Category 1, Category 2, and Category 3 hazard facilities, systems, processes, or operations. This effort and subsequent review must, at a minimum, consider environmental, safety, health, technical, operational, programmatic and administrative activities. The $O R R$ is used as a contractor line management tool for making initial start and restart decisions. It is the intent of this policy to establish the requirements for Mound OR and ORR projects.

\section{SOOPE}

This program applies to all kound operations requiring startup or restart autborization.

Subject to written exception/direction of the cognizant area office, DOE-AI Field office, or DOE Headquarters, ORRs shall be performed under any of the following circumstances:

1. NeN

-Initial start of a new activity.

-Initiation of a major new process or operation.

2. Nodification or Addition

- Hodifications to an existing facility or to a major system, process or operation, which potentially effects operational readiness.

3. Restart

-Restart of a facility, major system, or major process after an outage of such curation as to have a potential impact on operational readiness.

-Restart of a facility, major system, or major process subsequent to a shutdown for cause (significant disnption, accident, energency, etc.).

-opon resolution of an "mmreviewed safety question".

4. Other

-Imposition of ORR requirements by the DOE. 
Two graded classes of review (ORR) are included:

* Ievel 1 ORR (ORR1) involves a complete Mound independent team review of the operational readiness activities. This team is chartered and reports to the affected Department Head. The review team's activities would normally be evaluated by a graded DOE Operational Readiness Evaluation (ORE) . Team.

* Ievel 2 ORR (ORR2) involves an internal line management review through the affected Department Head. The readiness would normally be assessed through a graded DOE ORE Team.

\section{PEOGRAM OBJECTIVE}

Mound's objective is to operate or conduct all activities at or below the acceptable level of risk to the public, employees, enviroment, government property, and production capabilities. ORRs shall be performed and documented to ensure that these facilities, systems, operations, and processes as designed, have control measures in place consistent with safety, health, and envirormental documentation, and will be operated by trained and qualified personnel using approved operating procedures.

\section{EXIIENT OF APPITCABIIITY}

A. Application

1. Mound operations are defined as those activities where Mound has assumed Envirommental, Safety and Health (ES\&H) responsibility, regardless of whether or not there is a facility involved. These activities can be detenmined by the contract provisions. Appliciable DOE Orders include $5610.10,5610.11$, and 5610.13.

2. This procedure is limited to those Mound operations that involve hazards classed as either category 1, 2, or 3. (Category 4 hazard operations require baseline concuct of operations Es\&H reviews.) A preliminary hazard screening using the Mound Hazard Class Determination form (Appendix A) should be used to assess the hazard class of the facility process or operation. Applicable DOE Orders for hazard definitions are DOE 5480.23 and DOE/AL 5481.1b.

Category 1 Hazard (High). The hazard analysis shows the potential for significant offsite consequences.

Category 2 Hazard (Moderate). The hazard analysis shows the potential for significant on site consequences.

Category 3 Hazard (IOW). The hazard analysis shows the potential for only significant localized consequences. 
Category 4 Hazard (Standard Industrial Hazard/Alone). If the hazard is determined to pose no potential offsite, on site, or localized consequences, then the hazard source is a routine hazard. (Reference, PLG, Consensus Method for Hazard Classification for DOE Safety Analysis Guidance, August 27, 1991.)

B. Exclusions

1. Operations having hazards only of a type and magnitude routinely encountered and/or accepted by the general public.

2. The muclear explosive safety of weapon designs and associated handling of assembled weapons.

3. Construction-related work activities.

REFEREFICESS SEe Appendix B.

DEFINIIIONS AND ACRONYMS See Appendix $C$.

BACERGROUND

A. The purpose of the $O R$ effort is to establish that facilities, systens and processes can be operated safely, will perform as - designed, will be operated by trained and competent personnel, that adequate consideration has been given to all hazards, and that operation will not create uncue risk to employees, the public, or the enviroment. Most importantly, items that reduce the risk or control hazarious materials or processes are identified along with pertinent specifications.

B. ORRs are initiated when the OR Team reports that the readiness effort (physical work, documentation, procedure closures, training, operator qualifications, etc.) is in advanced stage of completion. An independent ORR team compiles a list of all required items identified in safety analysis, safety analysis reports, technical safety appraisals, accident investigations, and corrective actions to identify everything that is required to operate at acceptable risk levels. The team then looks for these itens, verifying that they are in place, can be used as required, and that there are no recognizable hazards that have not been addressed. Only after all critical-for-startup or critical-forrestart items are in place and operators are trained and qualified can an activity be declared ready. If an item is not in place, the review flags that item for inmediate attention.

c. Once an ORR is campleted the activity is declared operationally ready by submitting a Readiness to proceed Memorandim. This menorancm initiates the DOE approval process, leading to an Authorization to proceed. The DOE shall independently verify the

$$
\text { I-3. }
$$


contractor's ORR through an ORE. Since the level of DOE involvement is subject to various extermal factors, sound policy is to perform as rigorous a review as warranted to assure, cost effectively, the readiness of the activity.

\section{RESPONSIBIIITIES}

a. Iine Organization

(1) Prepare the facility so that it will be operated safely in accordance with applicable DOE orders, Mound policy and procedures, and within the authorization basis or envelope of safety. Guidelines for preparing for an ORR should be used for this purpose (OR/ORR Procedure I, Contractor Operational Readiness).

(2) Propose the levels of $O R R$ and startup approval required based on criteria in this document and obtain the appropriate Department Head and Dayton Area Office (DAO) concurrence.

(3) Request the responsible Department Head appoint an ORR Chaiman and charter a team when the facility is ready as described in (1) above. (The line organization will submit a proposed charter with this request.)

b. ES\&H Department

(1) Provide independent Ieview support to insure that a facility or process complies with ES\&H standards. (Reference MD-10374.)

c. Responsible Department Head

(1) Assure overall quality of the OR/ORR process.

(2) By use of the line organization reconmendation, the facility status, and ORR criteria, establish if an ORR is needed and what level of approval is required. Formally notify DaO of the intent to perform an ORR.

(3) Appoint and charter an ORR chainnan and team (OR/ORR Procedure II, Contractor Operational Readiness Review).

(4) Approve the ORR team plan. (Provide DOE DRO with information copies.)

(5) Review the results of the ORR and submit a Memorandum to Proceed" with a Copy of the Final ORR Report to DAO. Memorancum initiates the DOE approval process and requests a DOE verification (Operational Readiness Evaluation).. 
(6) Support the administrative requirements of the DOE-ORE team if required.

(7) Approve the start-up upon receipt of the DOE Authorization to Proceed Memorancim.

(8) Assure needed support for corrective actions.

d. $\mathrm{ORR}$ Team

(1) Write an ORR plan (OR/ORR Procedure II).

(2) Obtain affected Department Head approval of plan.

(3) Review plan with Dao, resolve any comments, and issue plan.

(4) Conduct the revien based on the directions given in the ORR procedure upon obtaining DAO approval of plan .

(5) Validate findings with the line organization.

(6) Write and submit the ORR reports.

* Interim Finding Report is the initial document which contains a comprehensive listing of all the ORR findings categorized per "A" or "B".

Category A findings are those involving deficiencies in systems, components, and structures, failure of which could significantly impact the safety of workers or others present in the operations area, the plant population, the public, or the environment. These findings must be resolved and closed prior to startup of the proposed operations.

Category B findings are those that have only minor safety impacts or which are not safety related. Category B findings do not necessarily have to be resolved prior to startup, but an approved action plan and scheciule for resolution of these findings must be available then.

* Sumary Management Report is an interim report that contains the validated category $A$ and $B$ findings, the corrective action plan, and a description of the methods used to track their closeout.

* Final Report closes the ORR process by combining the Summary Management Report, the Category $A$ and $B$ action plans, and the resolution of category A Findings. 
e. Manager OR Implementation

(1) Provide technical support for operational readiness and operational readiness reviews.

(2) Serve as Mound focal point and liaison for DOE ORR coummication.

\section{CRITHETA FOR THE NIMED FOR AN ORR}

The matrix in Figure 1 describes the level of ORR needed. All ORRs will require a DOE Authorization to Proceed Memorandum for start-up.

I. New Facilities, systems, Operations or Processes These are facilities, systems, etc., which may not be covered by an existing SAR or a DOE accepted substitute for a SAR (i.e. a safety assessment or risik analysis). These projects will require the develogment of the SAR or SAR substitute before an ORR can be performed.

- Risk Analysis approved by Mound Iine Management; ES\&F Management, and DOE DPO.

- Safety Assessment (SA) with Operaticnal Safety Requirements (OSR) approved by DOE AL.

- Technical Safety Requirements (ISR) approved by DOE AI

(possibly DOE Headquarters).

- SAR approved by DOE AI (possibly DOFl Headquarters).

The level of Mound ORR for a NEN IFCIIIIY is based upon Category hazard determination.

II. Modifications or Additions To Facilitjes, systems, Operations or processes

An ORR is required if modifications ol: additions affect the operational readiness of a facility ol: major system, process, or operation. The primary factors that determine this effect are: - The hazard level created by the modification/addition is new or different from the approved operation.

- The changes required are not covered under the existing SAR or approved safety documentation.

The level of ORR for a MODIFICAIION/ADDIIION is determined by the hazard level, ORR1 for high/moderate, ORR2 lor low, and baseline concuct of operation review for standard incustrial hazard (SIH)/none.

III. Restart of Facilities systems, operations or processes

A restart of an operation after shutdown for safety reasons is covered by SEN 16B-91 and by Mound Policy and Procedure 9342, Fork Curtailment/Restart. A shutdown is defined as a cessation of operation which is formally documented by the authority taking this action. A tellporary cessation or limiting of operations by the operating group to resolve a safety question or to adjust the process will not require an ORR unless accompanied by a formal written shutdown notice. 
The level of ORR for a RESTARI Project would be based upon the hazard determination or according to the authority responsible for shutdown (i.e. Any DOE shutdown would autamatically require an ORR1). 
ORRI/ORR2 DECISION MATRIX

\begin{tabular}{|c|c|c|c|}
\hline \multirow{3}{*}{$\begin{array}{l}\text { OR PROJECT } \\
\text { NEW FACIIITY } \\
\text { MOUND } \\
\text { DOE }\end{array}$} & \multicolumn{3}{|c|}{ HAZARD CATEGORY } \\
\hline & CATEGORY I & CATEGORY 2 & CATEGORY 3 \\
\hline & $\begin{array}{l}\text { ORRI } \\
\text { ORE }\end{array}$ & $\begin{array}{l}\text { ORRI } \\
\text { ORE }\end{array}$ & $\begin{array}{l}\text { ORR2 } \\
\text { ORE * }\end{array}$ \\
\hline $\begin{array}{l}\text { MODS/ADDITIONS } \\
\text { MOUND } \\
\text { DOE }\end{array}$ & $\begin{array}{l}\text { ORRI } \\
\text { ORE }\end{array}$ & $\begin{array}{l}\text { ORRI } \\
\text { ORE. }\end{array}$ & $\begin{array}{l}\text { ORR2 } \\
\text { ORE * }\end{array}$ \\
\hline $\begin{array}{l}\text { RESTART } \\
\text { MOUND } \\
\text { DOE }\end{array}$ & $\begin{array}{l}\text { ORRI } \\
\text { ORE }\end{array}$ & $\begin{array}{l}\text { ORRI } \\
\text { ORI } \\
\text {. }\end{array}$ & $\begin{array}{l}\text { ORR2 * } \\
\text { ORE * }\end{array}$ \\
\hline
\end{tabular}

ORR2 * = AnY DOE Shutdown of a Category 3 will require an ORRI level review.

ORE * = DOE Graded Review.

ORRI A complete Mound independent team review of operational readiness activities.

ORR2 An operating management review through the responsible Mound Department Head.

Figure 1.. ORR1/ORR2 Decision Matrix 
SECTION:

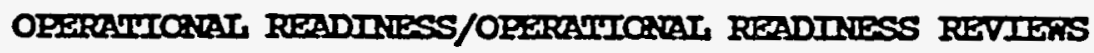

TIIIE:

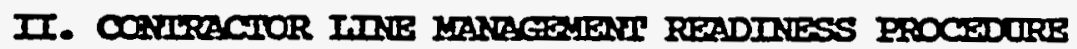

\section{PURPOSE}

The purpose of this procedure is to describe Mound's process for achieving line management, operational readiness for facilities, systems, operations, and processes.

\section{SCOPE}

This procedure applies to all Mound operations requiring startup and restart authorization.

\section{OBTECITVE}

Mound's objective is to operate all activities at or below an acceptable level of risk to the public, employees, enviromment, government property, and production capabilities. The operational Readiness (OR) process is intended to establish as rigorous and cost effective preparation as practical regardless of the subsequent verification Ieview (i.e. Operational Readiness Review, ORR, DOE Operational Readiness Evaluation, ORE).

\section{RESPONSIBIIITIIES}

- The line organization's operational Readiness Team (OR) is responsible for preparing the facility for safe operation (not the ORR team). This preparation should proceed independently and prior to the ORR.

- The ES\&H Department is responsible for providing independent review support to insure that a facility or process cormilies with ESEH standards.

PROCFDURE (Reference Figure 1, Operational Readiness Process)

OR Project Leader
1. Determine Hazard Ievel of project.

- Use Moumd Hazara Class Detemination Form as initial assessment (Reference Appendix A). 
Manager, Radiological and Industrial safety
- Review against existing safety envelope to determine if additional documentation is recpuired for clarification. (Safety envelope = approved DOE SAR, OSR, SA, Or an RA)

- Obtain Facility mgineering, Safety, and oversight comittee support as necessary.

2. Submit Mound Hazard Class Determination to Manager, Radiological and Incustrial safety.

3. Approve Hazard Class Determination. Reference DOE 5481.1b, DOE 5480.23, and "Consensus Method for Hazard Classification for DOE Safety Analysis", PIG, 8/27/91.

category 1 (High). If a given hazard source has the potential for significant off site consequences, then the hazard source is a category 1 hazard.

Category 2 (Nloderate). If the hazard source does rot pose offsite consequences but has the potential for significant on site consequences, then the hazard source is a category 2 hazard.

Category 3 (INW). If the hazard source does not pose offsite or on site consequences but has the potential for significant localized consequences, then the hazard source is a category 3 bazard.

Category 4 (inIf/None). If the hazard is determined to pose no potential offsite, on site, or localized consequences, then the hazard source is a "routine hazard".

4. Inform OR team of additional safety envelope requirements.

Risk Analysis (RA)

Safety Assessment (SA)

Safety Analysis Report (SAR)

Technical safety Requirements (ISR) 
OR Project Ieader

Department Head

OR Project Ieader
5. Propose the ORR level along with the rationale used, proposed project milestones, and estimate the date for the start of the ORR. (Figure 2, ORR1/ORR2 Decision Matrix)

ORR1 requires a camplete Mound independent team review of the state of operational readiness. The review team's activities is subject to an evaluation of a DOE Operational Readiness Evaluation (ORE) Team. This level is required for category 1 and 2 hazard classification.

ORR2 requires an internal operating management review by the responsible Department Head. The readiness is normally assessed by DOE through an evaluation by a DOE Area Office Graded ORE. This level of review is required, as a minimum, for category 3 classifications.

(Category 4 Hazard Classification projects require the baseline readiness efforts as outlined by Mound's Conduct of Operations Procedures.)

6. Obtain concurrence from the responsible Department Head.

concurrence for the ORR Ievel and approval level must be formally documented.

7. Inform DAO of the ORR level, ORR Schedule, and the proposed approval level.

8. Prepare and make available the following documentation as appropriate according to Figure 3, Operational Readiness Matrix Requirements.

- Conduct of Operations Self-Assessment survey. (Reference Appendix $D$, example.)

Survey and Mound Operations Mamual, MD-10361, are available from the Noumd Conduct of Operations Program Manager.

- A MORI type system analysis of the area under review (DOE 76-45/4, SSD C-4 Revision 2). 
- An approved "Hazard class

Determination" (Reference \#3. above).

- A project ES\&H Hormal Operations Readiness Check Sheet and associated documentation (Reference Appendix E.)

Checklist shall be approved by Mound's Independent Safety Revies Cordinating comittee.

Documentation must include:

-Criteria of Review

-scope of Review

-Basis of Review

-All Findings of Review

-Final appreved resolutions of

Findings

- The appropriate approved safety documents.

- General operating Procedures

-A formal Risk Assessment (RA)

-A Safety Assessment (SA)

- operational' Safety Requirements (OSR)

-Technical safety Requirements (ISR)

-A final Sarety Analysis Report (SAR)

- Approved ani documented operating and safety procedires for equipment and facility operation.

These proceitures must be up to date, reflect current DOE/AI Orders, the OSR or TSR (or other approved safety envelope document), and document the require- ments for configuration control of procectures, hardware and drawings.

Additionally, documented results of procedure wallkthroughs must be available.

- A quality pilan for the facility and process.

In the context of operational readiness, the quality plan must describe the configuration control for maintaining the safety ervelope. 
- Appropriate as-built drawings for the facility, process, and equipment.

(These drawings document original design intent and are covered by Mound Drawing control and Approval procedures.)

- Calibration and maintenance records and manuals for the process and equipment.

Documentation of compliance with DOE 4330.4A Maintenance Management Program.

- Documentation of personnel qualifications, training requirements, and completed training. Documentation includes evidence of personnel understanding of the general operating procedure, OSR or TSR, and ICOS.

- Records of recent external safety reviews and corrective actions taken.

Documentation of recent normal safety reviews with corrective actions taken.

Particular emphasis should be placed on the actions resulting from any related accident investigation.

- A documented program to verify that IOOs are met prior to any operation that requires IOO surveillance.

In addition, the following should be available:

- The system hardware for inspection.

Design information, acceptance test records, and dry Iuns may be requested by the ORR and ORE.

- Operators and key management for interviews. The attitude and knowledge of operators and management will be an important consideration in the ORR. 
9. Request the Deparlment Head approval of readiness effort.

o. submit operational readiness report sumarizing effort and presenting supporting documentation (or note location of supporting documentation) to Senior Manager. 
OPERATIONAL READINESS (OR)

PROCESS

PAGE 1 OF 2

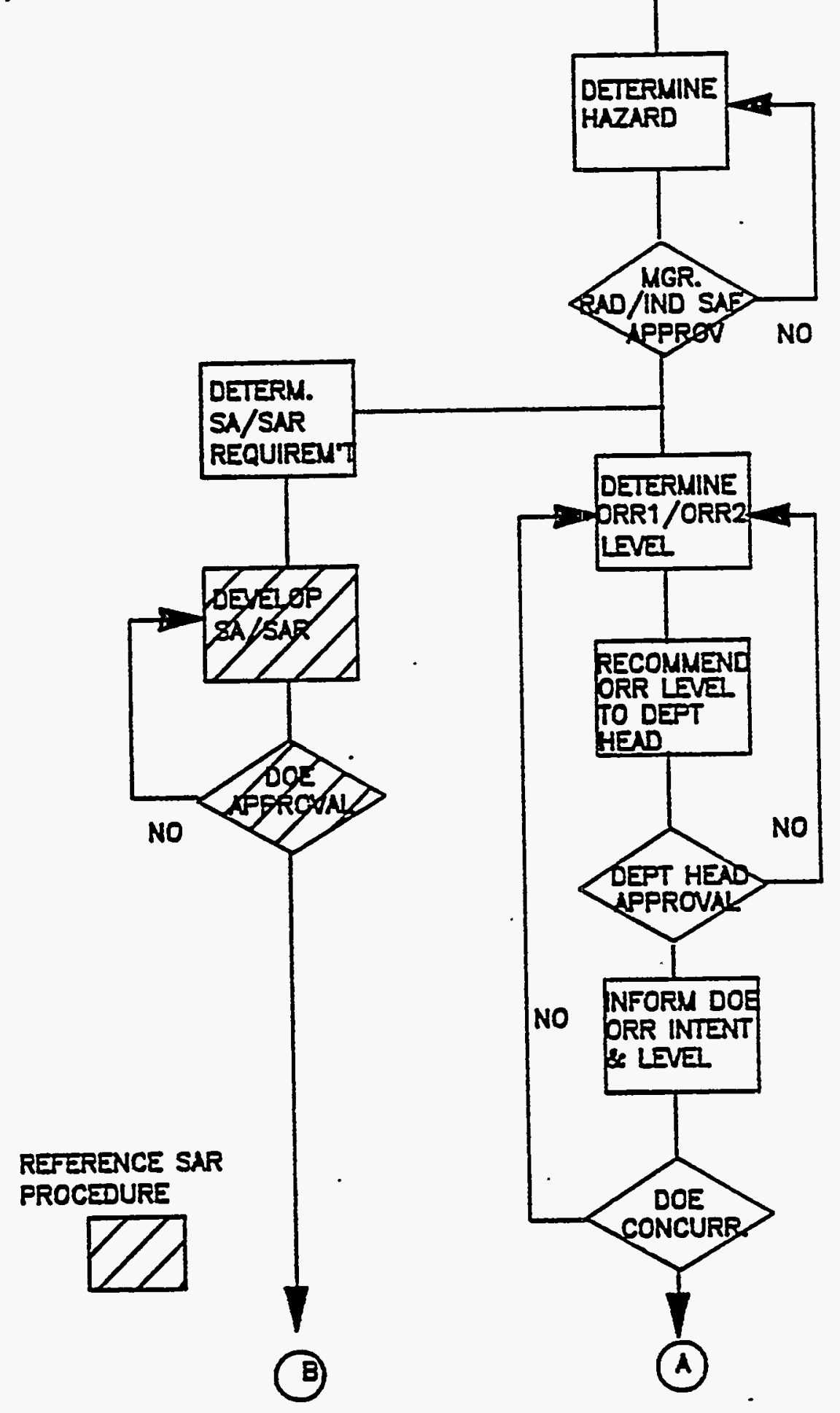

Figure 1. Operational Readiness Process II-7. 
OPERATONAL READINESS (OR)

PROCESS

PAGE 2 OF 2

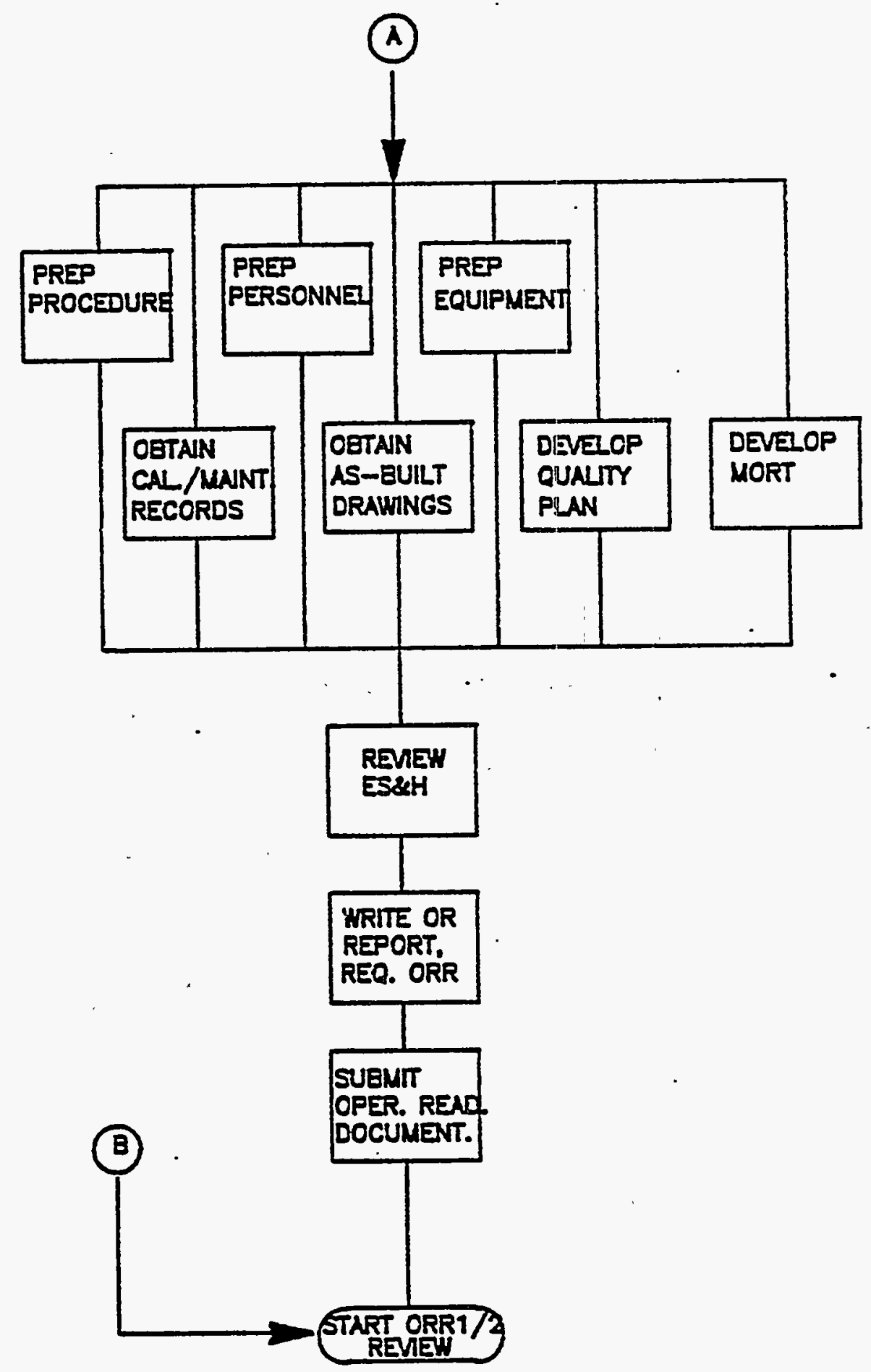

Figure 1. Operational Readiness Precess (Continued) II-8. 
ORRI/ORR2 DECISION MATRIX

\begin{tabular}{|c|c|c|c|}
\hline \multirow[b]{2}{*}{ OR PROJECT } & \multicolumn{3}{|c|}{ HAZARD CATEGORY } \\
\hline & CATEGORY 1 & CATEGORY 2 & CATEGORY 3 \\
\hline $\begin{array}{l}\text { NEW FACILITY } \\
\text { MOUND } \\
\text { DOE }\end{array}$ & $\begin{array}{l}\text { ORRI } \\
\text { ORE }\end{array}$ & $\begin{array}{l}\text { ORRI } \\
\text { ORE }\end{array}$ & $\begin{array}{l}\text { ORR2 } \\
\text { ORE * }\end{array}$ \\
\hline $\begin{array}{l}\text { MODS/ADDITIONS } \\
\text { MOUND } \\
\text { DOE }\end{array}$ & $\begin{array}{l}\text { ORRI } \\
\text { ORE }\end{array}$ & $\begin{array}{l}\text { ORRI } \\
\text { ORE }\end{array}$ & $\begin{array}{l}\text { ORR2 } \\
\text { ORE * }\end{array}$ \\
\hline $\begin{array}{l}\text { RESTART } \\
\text { MOUND } \\
\text { DOE }\end{array}$ & $\begin{array}{l}\text { ORRI } \\
\text { ORE }\end{array}$ & $\begin{array}{l}\text { ORRI } \\
\text { ORE }\end{array}$ & $\begin{array}{l}\text { ORR2 * } \\
\text { ORE * }\end{array}$ \\
\hline
\end{tabular}

ORR2 * = AnY DOE Shutdown of a Category 3 will require an ORRI level review.

ORE * = DOE Graded Review.

ORRI A complete Mound independent team review of operational readiness activities.

ORR2 An operating management review through the responsible Mound Department Head.

Figure 2. ORR1/ORR2 Decision Matrix II-9. 
OPERATIONAI READINESS REQUIREMENTS

MATRIX

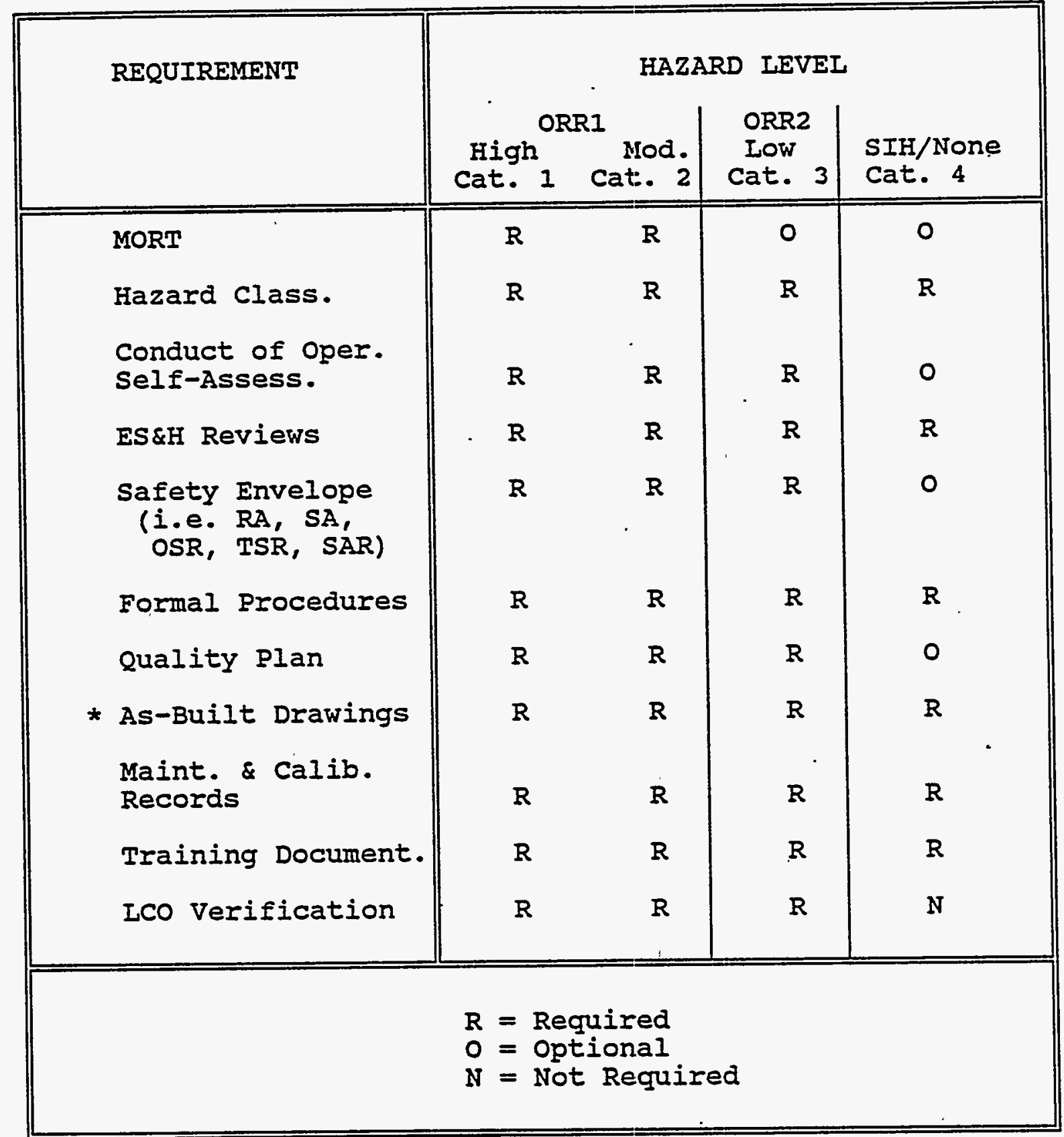

* Appropriate level of as-built drawings.

Figure 3. Operational Readiness Requirements Matrix 
SECIION:

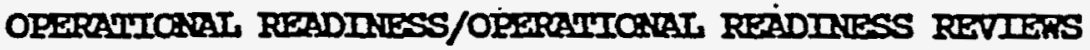

TIILE:

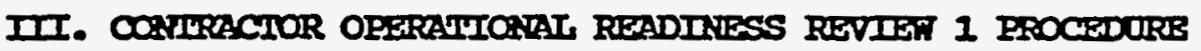

PUREOSE

The purpose of this procedure is to describe kound's operational readiness review process.

\section{SOOPE}

This procedure covers the Mound graded level 1, HIGH or MODERATE Hazard, of operational readiness review. ORRI involves a complete Hound independent team review of the operational readiness

activities. The review team's activities would nomally be evaluated by a graded DOE Operational Readiness Evaluation (ORE) Team.

ORR1 PROCFIDURE (Reference Figure 1, ORR1 Process)

DOE DAR Da

Senior Manager

Department Head
1. Schedule DOE ORE and provide ORE Plan information.

2. Review readiness documentation and facility.

3. Provide a formal briefing for appropriate Department Head.

Briefly review documentation supporting readiness of project. (Reference Figure 2, Operational Readiness Requirements Matrix)

4. Subnit appropriate ORR1 documentation for Department Head approval.

A request for an ORRI chairman and team. A draft ORR1 Team Charter. (Reference example, Appendix F.)

A list of potential ORRI Chairmen.

5. Review the request for an ORRI fram the Iine Organization.

6. Issue the final ORRI charter which includes:

- Purpose of the ORRI;

- Ievel of ORR1 approval ultimately required; 
ORRI Chairman

Department Elead

ORRI Chaiman
- The specific operations to be covered;

- Proposed tinie frame of ORRI completion;

- The person in the line organization who will serve as point of contact:

- Special resources required or situations to be addressed.

7. Appoint the ORRI chaiman per the following criterbia:

- Be independent of the organization being reviewet:

- Have Mound training in conducting ORRS;

- Have technical familiarity with the activity to be reviewed:

- Have had experience in leading safety investigations such as an accident investigation;

- Have demonstrated leadership skills;

- Be able to devote enough time and conmitment to produce a quality review in a reasonable time frame.

8. Detemine resources required for review and reccmmend ORRI team. Team criteria includes:

- Be independent of the organization being reviewed and, if possible the Operational Readiness Process for the facility in çuestion;

- Be knowledgeable in a discipline relevant to the review such as quality, ESEI or the technology area being reviewed;

- Have time and be available to provide a quality preduct in a timely manner.

9. submit tean recormendations to affected Depariment Hiead.

10. Approve ORJ1 team selection.

11. Develop the ORRI Plan based on the ORRI Charter.

-Assemble team for plan development as required.

-Develop ORR1 Team MORT type logic or reference the operational readiness MOPT as required. 
Department Head

DOE DAO

ORRI Team
-Document team methodology for determining category A Findings, Category B Findings including procedure for changing finding categories.

12. Submit ORRI Plan to affected Department Head.

-Fomat contents per fppendix G.

Note: The ORRI and ORE should be scheculed relatively close in order to avoid questions related to the maintenance of declared readiness.

13. Approve plan and send a copy to the DOE Area Office for concurrence.

14. Inform Mound of ORRI Plan concurrence.

15. Start review as near as practical to the specified dates as they appear in the ORRI Plan.

\section{(a) Initial Entry}

* The Operational Readiness Team should prepare a detailed briefing covering the items listed in contractor operational Readiness Procedure, Figure 2. Operational Readiness Requirements Matrix, and any other cocumentation shown important by the MORr analysis. Documentation of these items should be presented to the ORRI Team before the initial meeting to allow review.

\section{(b) Operation Review}

* Physical Review

This will involve direct verification of the specific harchare, personnel, management control, documentation and programmatic areas to be reviewed, along with additional checking within the associated areas at their logical interfaces.

For example:

- Human factor engineering considerations;

- Conformance and adequacy of design;

- Conformance with quality checks;

- Conformance with component and systen operation checks;

- susceptibility to damage;

III-3. 
- Conformance with calibration and maintenance requirements;

- Availability of spare parts.

As a minimm, the related interfaces of documentation and management controls include:

- Approved sariety documentation coverage (SA Or SAR) :

- Completeness of as-built system;

- Correctness and completeness of operating provecures;

- Completeness of operation:

- completeness of manuals and

documentation for maintenance and operations;

- Enviromential reviews:

- Safety and liealth reviews. (Reference documentation supporting ES\&I Normal Operations Readiness Checksheet, Appendix E.)

NOTE:

The physical revien is a final verification by the ORRI Team that all recognizable hazards have been identified in the workplace and that the appropriate actions have been taken to protect the enviromment and personnel safety and health.

* Personnel Review

Examples include:

- Mraining and certification of operating personnel;

- Denonstrated knowledge/capability of personnel.

- Relevant Mound Job Evaluation

Documents (JED'S).

- Relevant personnel Job Results

Analyses (JRA'S).

- Relevant medical certifications.

* Administrative Systems Revien This will inrolve a review of pertinent acministrative/control documents as well as other comnunica- tions used in the management of: the operation to assess the most effective acininistrative system. Examles include job schedules, job instructions and procedures, training plaus and records, instructions to the operational personnel, and conduct of gperations self assessment surveys. 
ORRI Team

The mechanisms/processes for elevating operating problems guickly to the highest appropriate level of management shall be evaluated. Assigment of responsibility for corrective action and for facility management gererally shall be considered in the evaluation.

The most recent procedures shall be used at all locations. Revien responsibility will be allocated in such a fashion as to maximize individ- ual expertise. In the case where procectures are not available at a particular time, the team shall review them as soon as they became available, assuring adequacy before completion of the ORR or its final phase.

The system for configuration management shall be reviewed, including document and design control, operating procecures, maintenance of appropriate as-built drawings, control of procurement and acceptance of replacement parts and materials, and the processes for selecting correct replacements.

16. Document, track, and maintain a current list of all observations, required follow-up actions, and findings throughout the course of the review.

All occurrences of nonconformance or inability to verify are to be noted. Any situation where the prepared checklist or verification guide seens to be inadequate, shall initiate an effort to upgrade the checklists or guides. The same pertains to obvious errors or cmission within them.

- As soon as practical, discussion of the observations and findings shall take place between team members and operating personnel in trying to assess their validity and if the finding/observation is determined to be valid. 
17. Coordinate the reinvestigation that may be necessary to provide a correct and consistent statement of the facts supporting the findings to be reported.

After release of the findings in draft form to the designated management representative, the line organization will be provided an opportunity to verify accuracy.

Items requiring correction shall be identified as:

"A"- findings are those involving deficiencies in systems, camponents, and structures, failure of which could significantly impact the safety of workers or others present in the operations area, the plant population, the public, or the enviroment. These findings must be resolved and closed prior to startup of the proposed operations.

"B"l- findings are those that have only minor safety impacts or which are not safety related. Category B findings do not necessarily have to be resolved prior to startup, but an approved action plan and schedule for resolution of these findings must be available then.

18. Issue the ORRI Interim Findings Report to the operational Readiness team, management, and the Ilepartment Head.

Concurrence of all findings is expected from the entire ORRI team. The existence of dissenting opinions or qualified sign offs is taken as an indication of incomplete facilitation or incomplete irvestigation and will need to be resolved.

Report format to include:

- Organization being reviewed;

- Type of review;

-References that have additional information concerning the finding, requirements, responses, or completed actions;

-Finding number;

-Date;

-Appraiser;

III-6. 
Operational Readiness Team

OR Project Leader and ORR1 Chainman
OR Project Leader

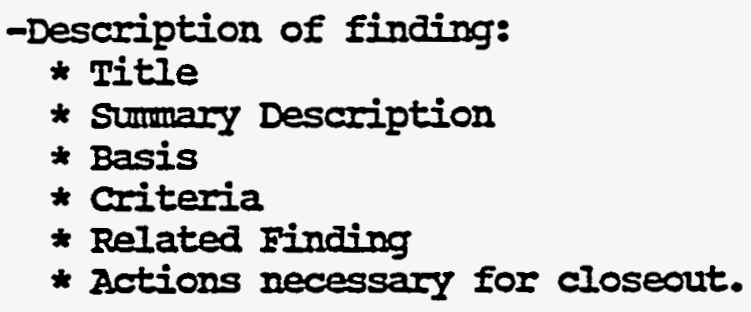

19. Develop corrective action plan for all findings.

Root cause analyses should be used as appropriate in developing corrective action plans.

20. Issue sumary Management Report to team members and Mound management, detailing the findings and corrective action plan. Format to include:

- Summary:

- Generic concernsi

- Conclusions:

- Recammendations to managementi

- Iisting of all validated category A findings:

- Iisting of all validated category B findings:

- Category A action plan:

- Category B action plan:

- Description of methods used to track closeout of all category $A / B$ findings.

In general, the sumary Management Report identifies the actions to be taken to ensure resolution of ORRI findings. It is used as a basis for the Final Report, and is included as an appendix to that document.

It should be noted that the Interim Findings and summary Management Reports may be combined depending upon the complexity of the OR Project.

21. Coordinate the OR team's implementation of the ORRI corrective action plan.

22. Report completion of all "gi" finding corrective actions to the ORRI Chairman.

Note: "B" findings must be tracked and reported on a monthly basis until resolved. 
24. Issue Final Report to the Department Head. Report format includes:

a. summary

Gives the reader a broad perspective of the reports contents. It will include:

- A brief statement of the pertinent facts.

- A list of significant findings.

- A recoumendation that the activity

is ready to operate at an acceptable level of risk.

- A statement of justification that all Category A findings bave been resolved.

- A statement that an approved plan has been provided for resolution of remaining Clategory B findings.

b. Introduction

states the pruppose of the ORRI, sumarizes the ways in which the review was expected to accomplish its purpose, and identifies team members. It is to include:

- Objectives sought;

- Scope of review:

- Period ofe performance of review;

- Identification of team members, individual expertise and areas of responsibilities.

\section{c. Review Process}

Prescribes tine methods used to accomplish the revien. This includes descriptions of how information was accumulated, recorded, correlated, verified, analyzed, and reported. It must also include the description of the methods used to gain perspective and ensure credibility, criteria used to evaluate information, and processes used to develop additional criteria.

\section{a. Findings}

Describes the findings per the Management Sumary Report:

- Includes a statement on the final

resolution of all Category A Findings.

- Includes; a statement on the approved corrective action plan for all

category E Findings. 
Department Bead

DOE Area Office.

OR Project Leader

Department Head

DOE Area Office

OR Project Ieader

Department Head e. Observations

Presents information on areas that may need management attention but do not result in findings.

\section{f. Concurrence}

Contains the signatures of all team members or statements explaining nonconcurrence.

\section{g. Appendices}

Contains documents or information not appropriate for the main body of the report but in support of it. This may include:

- Team members' biographies:

- Additional sources of information;

- Findings reports;

- ORR1 charter directives, etc.

25. Approve final report and send copies with "Memorandum to proceed" to DOE Area office.

Memorandum states Mound's readiness for a DOE Operational Readiness Evaluation (ORE).

26. Conduct ORE.

An ORE basically has the abjective of verifying the completeness of the contractor ORRI.

27. Issue ORE Interim Report on findings.

28. Develop and subitit Corrective Action Plan.

29. Approve ORE Corrective Action Plan and forward to DOE Area Office for concurrence.

30. Obtain corrective Action Plan approval.

31. Track Corrective Actions to completion and submit final ORE Corrective Action Report.

32. Approve final ORE Corrective Action Report and submit to DOE Area Office.

III-9. 
DOE Area Office

Department Head
33. Verify corrective actions.

34. Issue "Authorization to Proceed".

35. Authorize operational startup. 


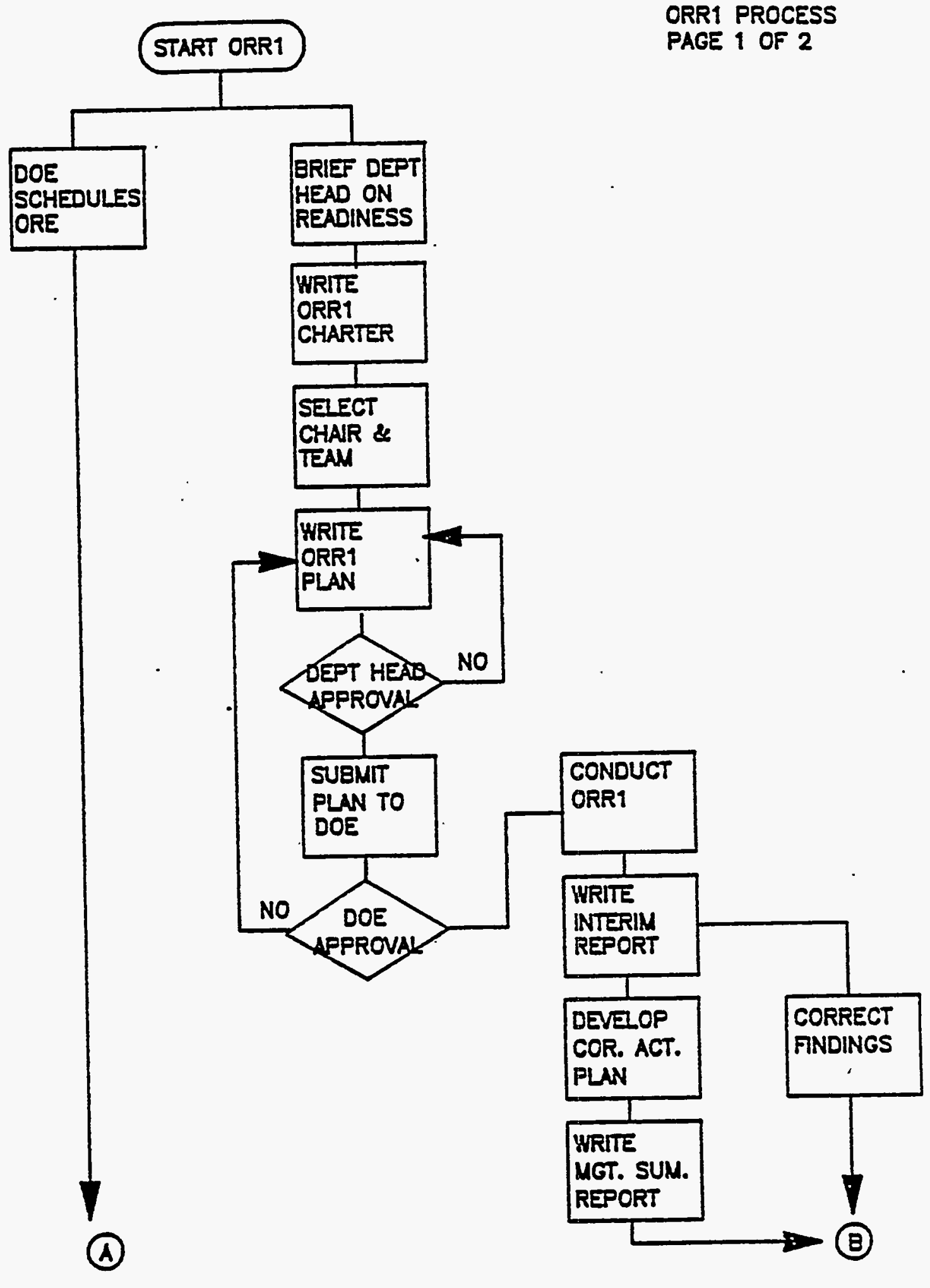

Figure 1. ORRI Process

III-11. 
SUBMIT.

FNAL

REPORT

No

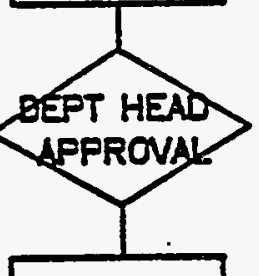

MRITE MENO

TO FROCEEY

SUEMIT
COR ACT

REPORT

CORRECT

FINDINGS

(EG\&G)

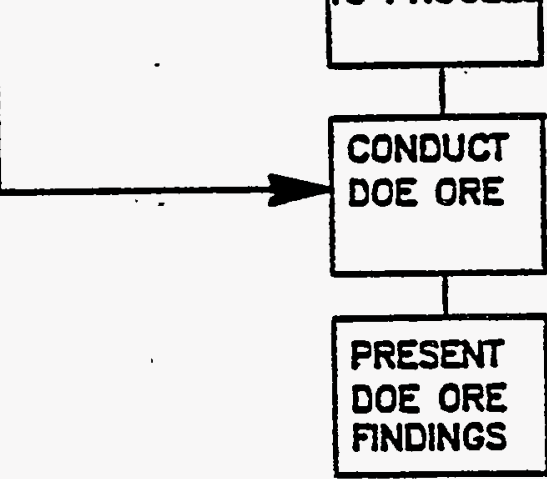

COR ACT

PLAN

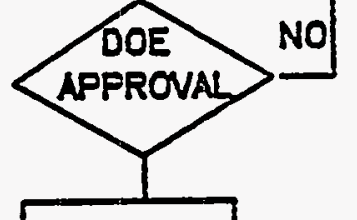

VALIDATE

CORRECT'NS

(DOE)

DOE ISSUE AUTH TO

PROCEED

START-UP

Figure 1. ORRI PIOcess

III-12. 
-OPERATIONAL READINESS REQUIREMENTS

MATRIX

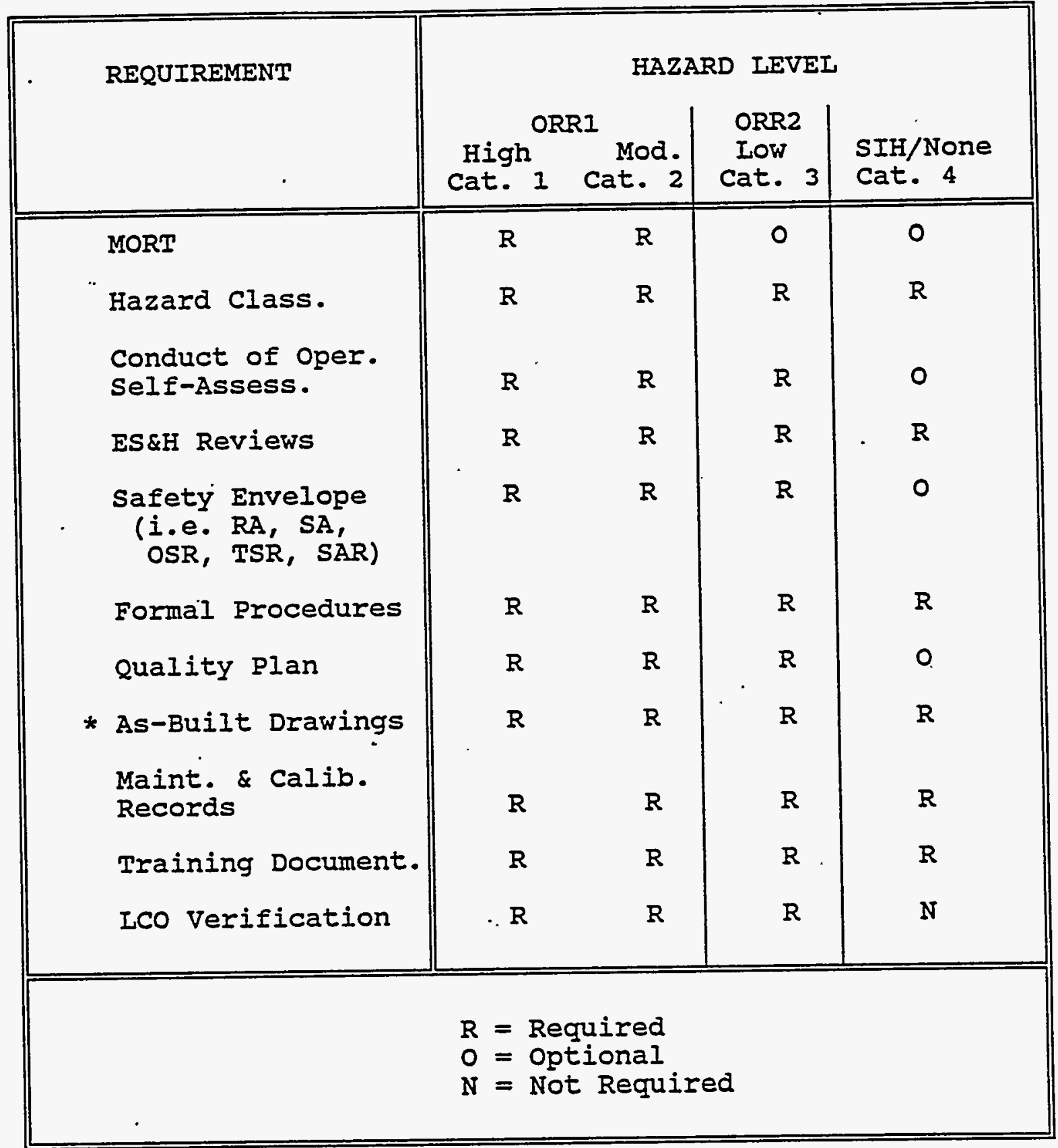

Appropriate level of as-built drawings.

Figure 2. Operational Readiness Requiremenț Matrix 


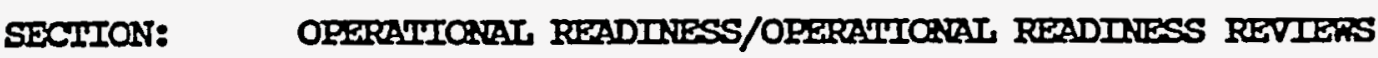

TIILE: IV. COATIRACIOR OFERAIIOARAL READIRNESS RREVIET 2 PROCEDURE

\section{PURPOSE}

The purpose of this procenure is to describe Mound's operational readiness review process.

\section{SCOFE}

This procedure covers the Mound graded level 2, Iow Hazard, of operational readiness review. ORR2 involves a rigorous Mound review of the operational readiness activities through an appropriate Department Head team review. The review team's activities would normally be evaluated by a graded DOE Operational Readiness Evaluation (ORE) Team.

ORR2 PROCEDURE (Reference Figure 1, ORR2 Process)

DOE DAO

Senior Manager
1. Schedule DOE ORE and provide ORE Plan information.

2. Review readiness documentation and facility.

\footnotetext{
* Physical Review

This will involve direct verification of the specific hardware, personnel, management control, documentation and progranmatic areas to be reviewed, along with additional checking within the associated areas at their logical interfaces.

For example:

- Human factor engineering considerations;

- Conformance and adequacy of design;

- Conformance with quality checks;

- Conformance with component and system operation checks;

- susceptibility to damage:

- Conformance with calibration and maintenance requirements;

- Availability of spare parts.
} 
As a minimm, the related interfaces of documentation and management controls include:

- Approved safety documentation coverage (SA or SAR);

- Completeness of as-built systemi

- Correctness and completeness of operating prosedures;

- completeness of operation;

- Completeness of manuals and documentation for maintenance and operations;

- Environmentar reviews:

- Safety and health Ieviews. (Reference documentation supporting ES\&H Normal Operations Readiness Checksheet, Appendix E.)

* Personnel Review

Examples include:

- Training and certification of operating personnel;

- Demonstrated knowledge/capability of personnel.

- Relevant Mound Jols Evaluation

Documents (JED's).

- Relevant personnel Job Results

Analyses (JRA.'s).

- Relevant medical certifications.

* Administrative Systens Reviea

This will involve a review of pertinent adninistrative/control documents as well as other conmanica- tions used in the management of the operation to assess the most effective administrative system. Examples include job schedules, job instructions and procedures, training plans and records, instructions to the operational personnel, and conduct of operations self assessment surveys.

The mechanisws/processes for elevating operating problens quickly to the highest appropriate level of management shall be evaluated. Assignment of responsibility for corrective action and for facility management generally shall be consideret in the evaluation. 
Department Head

Senior Manager
The most recent procedures shall be used at all locations. Review responsibility will be allocated in such a fashion as to maximize individ- ual expertise. In the case where procedures are not available at a particular time, the Senior Manager shall review them as soon as they become available, assuring adequacy before calloletion of the ORR.

The system for configuration managenent shall be reviewed, including document and design control, operating procedures, maintenance of appropriate as-built drawings, control of procurement and acceptance of replacement parts and materials, and the processes for selecting correct replacements.

3. Select a department review team. For example:

- Manager Operational Readiness Implementation.

- Independent technical support such as a chairman of a safety overview cormittee.

-ES\&H representative such as the chairman of the Independent Safety Review Coordinating conmittee.

4. Provide a formal briefing for Department Head Team.

Briefly review the operational readiness effort and documentation that supports readiness status. (Reference step 1.)

Review documentation supporting walkdown of procedures.

5. Confuct a facility tour for Department Head Team.

This tour is a final verification by the Department Head Team that all Iecognizable hazards have been identified in the workplace and that appropriate actions have been taken to protect the enviromment and personnel safety and health. 
Department Iead

Senior Manager
6. Document any findings in a formal Interim Report.

Report format to include:

a. Sumary of Review.

-Date

-Appraisers

- Methodology

b. Description of findings

-Title

-sumary Description

-Basis

- Criteria

- Related Finding

-Actions Necessary for Closeout

Root Cause analyses should be used as appropriate in developing corrective action plans.

7. Approve Int:erim Report.

8. submit Final ORR2 Report for approval.

Final ORR2 report includes resolutions of findings resulting from Department Head facility tour.

Report format: includes:

a. Sunmary

Gives the reader a broad perspective of the reports contents. It will include:

- A brief statement of the pertinent facts.

-A list of significant findings.

-A recommendation that the activity is ready to operate. at an acceptable level of risk.

-A statement of justification that all Category A findings have been resolved. -A statement that an approved plan has been provided for resolution of remaining Category B findings. 
Department Head Review Team

Department Head b. Introcuction

states the purpose of the ORR2, summarizes the ways in which the review was expected to accomplish its purpose, and identifies Department Head's team members. It is to include:

- Objectives sought;

- Scope of review:

- Period of performance of review;

- Identification of Department Head Team members, individual expertise and areas of responsibilities.

c. Review Erocess Prescribes the methods used to accomplish the review. This includes descriptions of how information was accumulated, recorded, correlated, verified, analyzed, and reported. It must also include the description of the methods used to gain perspective and ensure credibility, criteria used to evaluate information, and processes used to develop additional criteria.

d. Findings Describes the findings per the Findings . Report:

-Includes a statement on the final resolution of all Category A Findings. - Includes a statement on the approved corrective action plan for all category $B$ Findings. ("B' findings must be tracked and reported on a monthly basis until resolved.)

e. Appendices Contains documents or information not appropriate for the main body of the report but in support of it. This may include:

- Additional sources of information;

- Findings report; etc.

9. Verify corrective actions.

10. Approve final report and send copies with "Memorandum to proceed" to DOE Area Office.

Memorandum states Mound's readiness for a graded DOE Operational Readiness Evaluation (ORE). 
DOE Area Office

OR Project Leader

Department Head

DOE Area Office

OR Project Ieader

Department Head

DOE Area Office

Department Head
11. Conduct ORE.

An ORE basically has the objective of verifying the conpleteness of the contractor ORR.

12. Issue ORE Interim Report on findings.

13. Develop and submit corrective Action Plan.

14. Approve ORH Corrective Action Plan and forward to DOE Area Office for concurrence.

15. Obtain corrective Action Plan approval.

16. Track Corrective Actions to completion and submit final ORE Corrective Action Report.

17. Approve final ORE Corrective Action Report and subnit to DOE Area Office.

18. Verify corrective actions.

19. Issue "Authorization to Proceed". 20. Authorize operational startup. 
ORR2 PROCESS

PAGE 1 OF 2

\section{START ORR2}

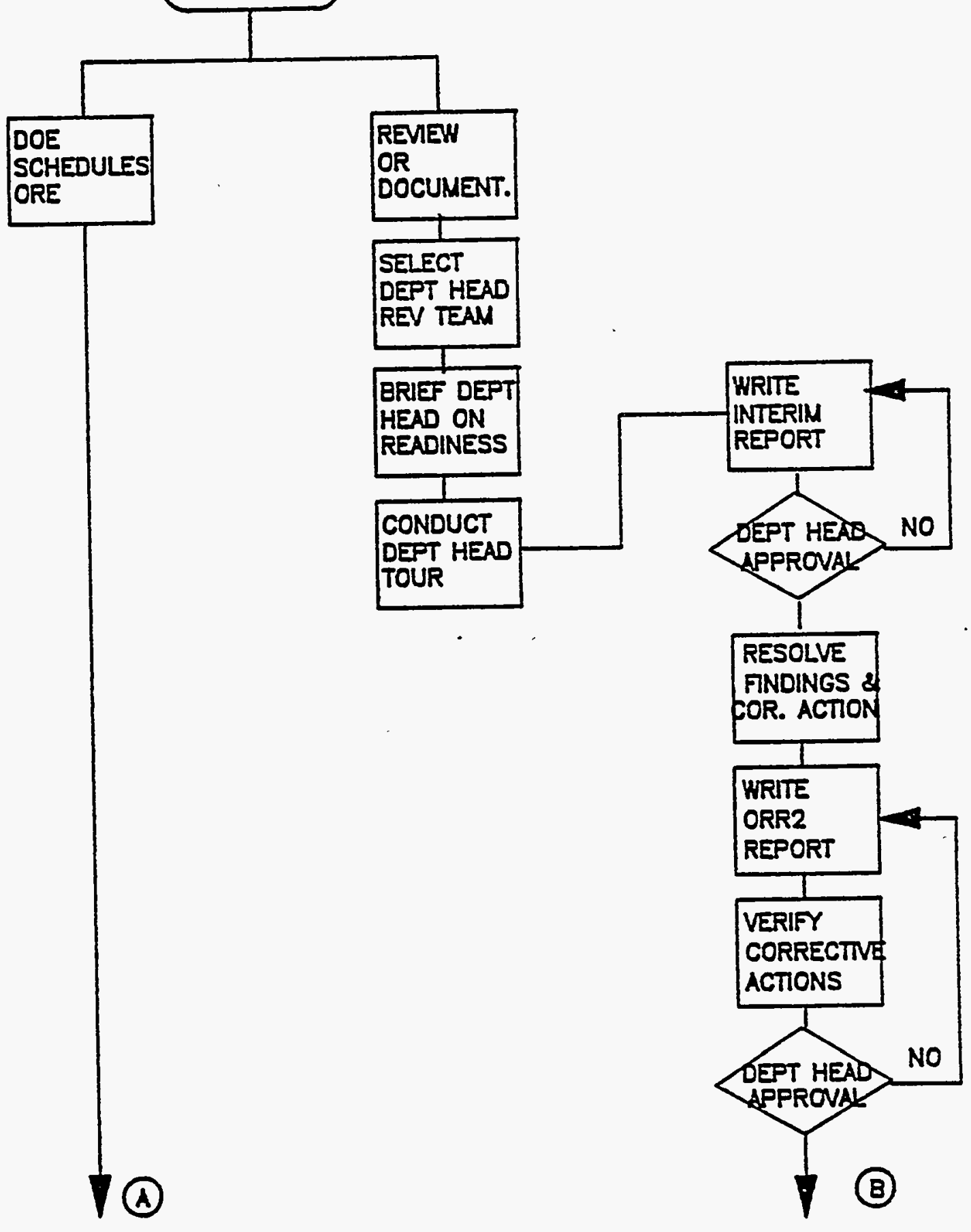

Figure 1. ORR2 Process 
()

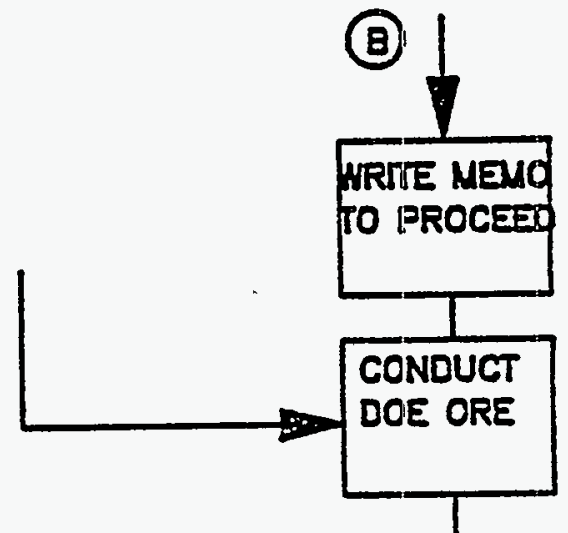

PRESENT

DCIE ORE

FINDINGS

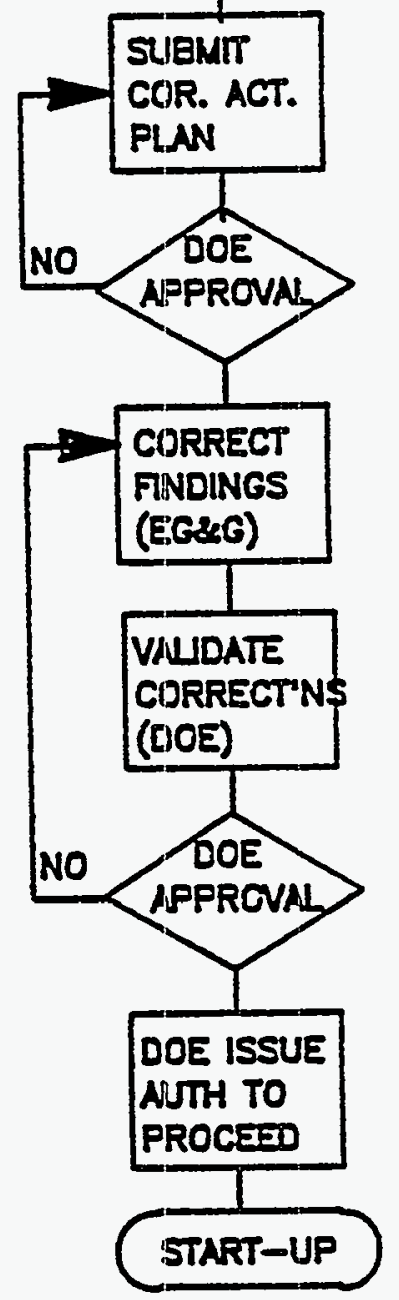

Figure 1. ORR2 Process 


\section{APPENDIX A.}



Bldg. No.:

Classifers:

HAZARD CLASS SUTHRY

Maximum Room Inventory, Ci or g:

Energetic Materials 6

Hazard Class: Hone $\square$, Low $\square$, Cat. \#4 Cat. \$3

), HT C

) HTO (

Moderate $\square$ Cat. $\# 2$

High $\square$

Cat. \#1
). $\operatorname{TRU}($ )

Nuclear Facility $\square$

Nuclear Facility : A facility those operations involve radioactive materials in such form and quantity that a significant nuclear hazard potentially exists to employees or the public.

Concurrence:

$$
\text { Building Manager }
$$

Appropriate Overvies Concurrence:

TESOC

TRUESOC

$\overline{\text { EMSOC }}$

$\overline{\text { LP\&EC }}$

PART A - PRELIHIKARY HAZARDS EVALUATIOM

Check all applicable boxes.

Energy Source Hazards - Circle the most significant energy hazards.

Electrical: capacitors, transformers, batteries, exposed conductors, high-voltage sources

Motion:

Gravity-Mass:

Pressure:

Chemical:

Heat/Fire:

Cold:

Radiant: pulleys, belts, gears, shears, pinch points, vehicles, mass in motion falling, falling objects confined gases, chemical reactions, stressed mechanical systems corrosive materials, reactive materials

electrical, steam, flames, solar, chemical reactions, combustible materials, flamable materials cryogenic materials, walk-in freezers

lasers, ultraviolet, infrared sources, magnetic fields, RF fields

others:

Q There are no energy sources of a magnitude capable of seriously injuring several facility occupants or causing injuries outside the facility. Injury may occur to a limited number of individuals within the facility due to the types of hazards associated yith office Hork, cold shop activities, etc.

Corment:

Monradioactive Material Hazards (toxic, carcinogen, pathogen, etc.)

(1) There are no hazardous materials of a type or magnitude capable of seriously exposing several facility occupants or causing serious exposures outside the facility. Hazardous materials are limited to typical quantities of maintenance, cleaning, and structural materials routinely encountered in offices, residences, workshops, etc.

Coment:

Energetic Materials - HE (UNO Class $1 . x$ Explosive)

口 If an activity in a room/lab had an MCE (Maximum Credible Event) limit up to and including 3 grams of Uxo class $1 . x$ Explosive, it is "standard Industrial Hazard" (SIH).

Energetic Materials - Thermite (UNO Class 4.1 Flamable Solid)

i] If an activity in a room/lab has an MCE limit up to and including 500 grams of UNO Class 4.1 flammable solid, it is sth.

Conment: 
口 There are no radiological areas. Radiation sources, if present, are limited to:

- those commercially available to the public and exempt from licensing requirements.

- encapsulated or sealed sources meeting the requirements of ANSI standard H542 or equivalent as determined by TRUESOC.

- instrument check sources.

- HT gas - if the inventory of a lab/room is less than 81 Uci ( $8.1 E-9$ g T2), it is "no"l hazard. Tritium-powered ExIT signs or similar NRC license itens of commercial origin are a part of the Mound sealed source program and the area in which these signs are located are considered "Wo Hazard", unless the signs are in a radiation-controlled area or other forms of $\mathrm{TZ}$ are present then, the hazard is based on those other quantities.

- HT liquid - if the concentration of the tritiated water liquid is less than 1 Ci/liter and the room/lab inventory is less than $8.1 E-9$ g T2(81 uCi) equivalent, it is "no" hazard.

Comment:

\section{Emironental Hazards}

(- Radioactive and hazardous materials are limited to types, forms and quantities that, if spilled, would present only a slight potential for health effects and negligible damage to the enviroment.

Corment:

If all of the above boxes are marked, designate "none" for the hazard class. For each category where the box is not marked, complete part 8 . The facility/operation hazard class is the highest class assigned.

Additional comments on hazards:

PART B - CATEEORIZATION OF LOM, HOOERATE, AND HIGH HIRZRD CLASSES

Energy Source Hazards

If not controlled, energy source(s) are capable:

- severely injuring several facility occupants and/or causing minor injuries outside the facility

- severely injuring individuals outside the facility and/or causing minor injuries offsite

- severely injuring individuals offsite

Monradioactive Material Hazards (toxic, carcinogen, pathogen etc.)

If dispersed, hazardous materials are capable of causing:

- serious overexposures to several facility occupants and/or exposures - linits outside facility

- serious overexposures outside the facility and/or exposures - limits offsite

- serious overexposures offsite

Energetic Materials Hazards - HE (UNO Class 1.X Explosive)

- If an activity in a room/lab has an MCE (Maximu Credible Event) limit greater than 3 grams HE of energetic materials, but less than $5 \mathrm{Kg} \mathrm{HE}$, it is "low" hazard.

- If an activity in a room/lab has an MCE limit greater than $5 \mathrm{Kg}$ HE but less than $227 \mathrm{Kg}$ HE of energetic materials, it is "moderate" hazard.

- If an activity in a room/lab has an MCE limit greater than $227 \mathrm{~kg} \mathrm{HE}$ of energetic materials, it is "high" hazard.

Hote: Room inventory limits of energetic materials will be utilized to classify the roon or lab.

Hote: Questionable hazard elassification projects should be presented to EMSOC for verification.

Energetic Materials Hazards - Thermite (UNO Class $4.1 \mathrm{Flammable} \mathrm{Solid)}$

- If an activity in a room/lab has an MCE limit more than 500 grams of a UNO Class 4.1 Flamable solid, it is "low" Hazard. (There is no upper limit for this material, "(ow" will never be exceeded.)

Hote: Questionable hazard classification projects should be presented t:o EMSOC for verification. 


\section{Hazard Classification Criteria for Tritiun Areas}

When a roon or lab has a non-dispersible operating condition only, that is:

- non-destructive operations with radioactive materials in solid form

- grouted or vitrified materials, or

- radioactive materials in Dot-approved shipping containers, other contaiment and/or materials configurations which render the radioactive material non-dispersible, (as determined by TESOC, case by case), then the roon or lab is considered to have a "low" hazard class.

HT Gas

- If the inventory of a room/lab is greater than 89 uci but less than $25 \mathrm{~g} \mathrm{r2}$, it is "low" hazard.

- If the inventory of a room/lab is between $25 \mathrm{~g} \mathrm{T2}$ and $250,000 \mathrm{~g} \mathrm{T2}$, it is "moderate" . hazard.

- If the inventory of a room/lab is greater than $250,000 \mathrm{~g} \mathrm{T2,} \mathrm{it} \mathrm{is} \mathrm{"high"} \mathrm{hazard.}$

HTO Liquid

- If the concentration of the tritiated water liquid is less than $1 \mathrm{Ci} / \mathrm{liter}$ and the room/lab inventory is greater than $81 \mathrm{uCi}$ but less than $250 \mathrm{~g} \mathrm{T2}$ equivalent, it is "low" hazard.

- If the concentration of the tritiated water liquid is more than $1 \mathrm{Ci} / \mathrm{liter}$ and the room/lab inventory is between $81 \mathrm{UCi} T 2$ and $2,500,000 \mathrm{~g} T 2$ equivalent, it is "moderate" hazard.

- If the room/lab inventory is more than $2,500,000 \mathrm{~g} \mathrm{T2}$ equivalent, it is "high" hazard.

Other

- Any room or lab is considered to have a "low" hazard class even without any tritiun inventory, as long as it is located within a radiation-controlled area.

Hote: Use maximun permitted (e.g. OSRs, RWPS) when possible for the room or lab inventory.

\section{Hazard Classification Criteria for TRU}

When a roon or lab has a non-dispersible operating condition only, that is:

- non-destructive operations with radioactive materials in solid form

- grouted or vitrified materials, or

- radioactive materials in DoT-approved shipping containers, pipe nipples, fireresistant safes, other contaiment and/or materials configurations which render the radioactive material non-dispersible, (as determined by TRUESOC, case by case), then, the room or lab is considered to have a. "low" hazard class.

When a room or lab has a dispersible TRU material inventory associated with a specific operating activity (see footnote 1 and 2 ):

- less than $A^{\star} E+01 \mathrm{Ci}$, the room or lab is considered to have a "low" hazard class.

- betueen $A^{\star} E+01 C i$ and $A^{\star} E+05 C i$, the roon or lab is considered to have a "moderate" hazard class.

- greater than $A^{\star} E+05 \mathrm{Ci}$ (where the value of "A" is a multiplication factor for a specific radionuclide and is listed in the footnote 3 , the room or lab is considered to have a "high" hazard class.

When a room or lab has a highly dispersible TRU material inventory associated with a specific operating activity (see footnote 1 and 2 ):

- less than $A^{\star E} E-02 \mathrm{Ci}$, the roon or lab is considered to have a "Low" hazard class.

- between $A^{\star E} E-02 \mathrm{Ci}$ and $A^{\star} E+02 C i$, the room or lab is considered to have a "moderate" hazard class.

- greater than $A^{\star} E+02 \mathrm{Ci}$, the room or lab is considered to have a "high" hazard class.

When a room or lab has greater than $45 \%$ minimum critical mass of fissionable material, it is considered to have "moderate" hazard class in terms of Huclear Criticality Hazard. 
Footnote 1: Highly dispersible is defined as:

- Operations with radioactive gases, vapors, aerosols, or substances that boil at $<100 \mathrm{c}$.

- Use of radioactive materials in combustible or explosive conditions.

- Use of radionuclides in dry, dusty operations.

- High-temperature or high pressure operations with or near radioactive materials.

- Use of pyrophoric radioactive materials.

Dispersible is defined as:

- Operations with radioactive liquids, powders, or particulate solids.

- Operations that can result in fractional releases of radioactive materials.

- Use of unsealed, non-combustible non-explosive liquids or compact solids in chemical processes or operations.

Footnote 2: Use maximm permitted (e.9. OSRs, RUPs) when possible for thi room or lab inventory.

Footnote 3: The values of "A", the multiplication factor for the source Rerm values, have been determined fron Exhibit 8, Radionuclide Groups, of "A PRACTICAL APPROACH TO HAZARD CLASSIFICATIOH" (Revision 1), authored by 0 . E. Lucas. Battelle, Pacific Morthwest Laboratories (PHL), Richland, Washington, 99352 , and are listed below:

Radionuclide

Th 232

An 241

Con 244

Pu 240

Cf 252

U 234

U 238

$$
\frac{\text { "A" }}{1.25}
$$

3.85

5.26

7.69

13.33

15.38

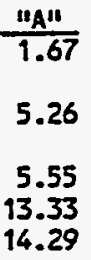

\begin{tabular}{|c|c|}
\hline$\frac{\text { ionucl ide }}{\text { Np } 237}$ & $\frac{{ }^{\text {"A" }}}{1.67}$ \\
\hline Pu 239 & 5.26 \\
\hline $\begin{array}{ll}\text { PU } & 238 \\
U & 233 \\
U & 235\end{array}$ & $\begin{array}{r}5.55 \\
13.33 \\
14.29\end{array}$ \\
\hline
\end{tabular}

u 233 
APPENDIX B 



\section{References}

1. DOE Order 4330.4A, Maintenance Management Program, October 17, 1990.

2. DOE Order 5000.3A, "Occurrence Reporting and Processing of Operations Information", May 30, 1990.

3. AI Supplemental Directive 54XA "Operational Readiness Review Program", November 27, 1991.

4. DOE Order 5480.19 , "ronduct of Operations Requirements for DOE Facilities", July 9, 1990.

5. DOE Order 5480.23, "Nuclear Safety Analysis Reports", April 30, 1992.

6. DOE Order 5480.5, "Safety of Muclear Facilities", Septenber 23, 1986. AI Order 5480.5, "Safety of AI Nuclear Facilities", July 17, 1987.

7. DOE Order 5481.IB, "Safety Analysis and Review system", September 23, 1986. AI Order 5481.1B, "Safety Analysis and Revien systems", Jamary 27, 1988.

8. DOE Order 5482.1B, "rnviroment, Safety, and Health Appraisal Program", Septenber 23, 1986.

9. DOE Order 5610.10, "Nuclear Explosive and Feapon Safety Programs", October 10, 1990.

10. DOE Order 5610.11, "Muclear Explosive Safety", October 10, 1990. AI supplemental Directive 5610.11, Nuclear Explosive Safety, Aungust 9, 1991.

11. DOE Order 5610.13, Joint Department of Energy/Department of Defense Nuclear Feapon system Safety, Security, and Control Activities", Cotober 10, 1990.

12. DOE Order 5700.6C, "quality Assurancel", August 21, 1991.

13. DOE Order 6430.1A, "General Design Criterial", April 6, 1989.

14. AI $Q C-1$, "General Requirements for the Establishment of Quality Control systems by AEC Contractors', 1955.

AI gC-2, "Quality Criteria, Design", 1985.

15. DOE (ERDA) MRNUAL 76-45/1, (SSDC-1), 'DCcupancy-Use Readiness Mamual", September 1975. 
16. DOE (ERDA) Manual 76-45/4, Rev. 2 (SSDC-4), "MOEr User's Mamual", Nay 1983.

17. DOE (ERDA) Mamual 76-45/8, (SSDC-8), "Standardization Guide for Construction and Use of Morr-Iype Analytic Trees", February 1977.

18. DOE Mamul 76-45/23, (SSDC-23), "Safety Alypraisal Guide", August 1982.

19. DOE Mamual 76-45/24, (SSDC-24), "Safety Assurance System Sumary (SASS) Mamal for Appraisal", September 1982.

20. DOE Namal 76-45/25, (SSDC-25), "Effective Safety Reviews", september 1982.

21. DOE Mamual 76-45/39, (SSDC-39), "Process Dperational Readiness and Operational Follow-On", February 1987.

22. SEF-16-91, "Approval for Restart of Facilities Shut Down for Safety Reasons and startup of Major New Facilities", November 13, 1991.

23. NE-1, "Procedure for Restart of Reactors and Non-reactor Nuclear Facilities", March 27, 1991.

24. Memorancum from Mary I. Walker to Managers, DOE Operations, "Guidelines for the Use of Readiness Reviews", February 25, 1987.

25. PIG, MConsensus Method for Hazard Classification for DOE Safety Analysis Guidance", August 27, 1991.

26. MD 10374, "Contractor Independent Safety Review and Appraisal System", April 27, 1992.

27. MD Acministrative Policy Mamal, Folicy 9342, "Fork Curtailment/Restart", July 9, 1992. 
APPENDIX C 
Activity A facility, a system, or a process that is the subject of an Operational Readiness Review.

Authorization Basis Those aspects of a facility design basis relied upon by DOE to authorize operation. These aspects are considered to be important to the safety of the facility operations. The authorization basis is cantised of the facility safety Analysis Report, the Technical Safety Requirements, DOE-issued Safety Evaluation Reports, and facility-specific commitments made in order to comply with DOE rules, Orders, or policies.

Authorization to Proced official notification by the appropriate DOE approval authority that an activity may start or restart operations.

Category A Action Plans A description of the methodology used to track, resolve, and close out category A findings.

Category A Findings are those Findings involving deficiencies in systems, camponents and structures failure of which could significantly impact the safety of workers or others present in the operations area, the plant population, the public or the enviroment.' Correction of category A findings is necessary to ensure safe operations. They include, but are not limited to, safety systems, process controls and proficiency measures. These findings must be resolved and closed prior to starting the proposed operation.

Category A Items are those systems, camponents, and structures, including portions of process systens, whose failure could adversely affect the enviroment or the safety and health of the public.

Category B Action Plans A description of the methodology used to track, resolve, and close out category B findings.

Category B Findings are those findings which have only minor safety impacts or which are not safety related. Category B findings do not necessarily have to be resolved before start-up but an approved plan and schedule for resolution of these findings must be available then.

Category B Items are those structures, systems, subsystems, and components necessary for everyday operations but not necessarily required for safety reasons. They are sometimes referred to as not-critical-for-start-up itens. 
Contractor/DOE Initiated An ORR is contractor initiated when the contractor takes the initiative to perform one. An ORR is DOE initiated when DOE asks the contractor to ferform one.

Decomissioning and Decontamination (DED) is the process of closing and securing a facility to: (1) Provide aclequate protection from radiation or hazardous material exposure, and (2) Isolate radioactive or hazardous materials contamination to permit controlled or unrestricted release of the fiacility for other uses.

DOE contractor is any prime contractor or subcontractor subject to the contractual provisions where DOE has elected to enforce ES\&H requirements by specific negotiated contract provisions.

Enviroment, Safety and Fealth (ES\&F) Proga:am encompasses those DOE requirements, activities and functions in the concuct of all DOE and DOE-controlled operations that are concerned with: controlling air, weter, and soil pollution; limiting the risk to the well-being of both operating personnel and the general public to acceptably low levels; and protecting property adequately against accidental loss and damage. Typical activities and functions related to this program include, but are not limited to, the following: environmental protection, occupational safety, fire protection, incustrial hygiene, health physics, occupational medicine, process and facility safety, nuclear safety, emergency prepareduess, cpuality assurance, and radioactive and hazardous waste managenent.

Facility Any equipment or structure having the potential for major impact on the enviroment, safety, or health of employees or the public. Exmles include accelerators, storage areas, fusion research devices, muclear reactors, production or: processing plants, coal conversion plants, magnetohydrodynamies experiments, windmills, hazardous disposal burial grounds, testing and research laboratories, and accomodations for analytical examinations of irradiated and unirradiated components.

Facility Representative For each major facility or group of lesser facilities, an individual or his or her designee assigned responsibility by the Head of the Field Organization for monitoring the performance of the facility and its operations. This individual shall be the primary point of contact with the contractor and will be responsible to the appropriate Program Secretarial officer and Head of Field Organization for implementing the requirements of AI supplemental Directive 54XA.

Field office is a departmental element located outside of the Fashington, D.C. geographical area.

Final Report A report based upon the sunmary Management Report, the Category A and B Action Plans, and the resolution of category A findings. This report will contain the operating organization's senior management concurrence with the assessment of operational readiness, and is forwarded, along with the memorandum to proceed, to WMOSD for further action by DOE, if recuired. 
Finding is a statement of fact concerning a condition in the facilities, systems, operations, or processes that was investigated curing the review. It may be a simple statement of proficiency, or a description of a deficiency. Both severity and potential consequences should be addressed in describing a deficient condition.

Hazard is a source of danger (i.e. material, energy source, or operation) with the potential to cause illness, injury, or death to personnel, or damage to a facility, or the enviromment without regard to the likelihood or credibility of accident scenarios or consequence mitigation.

Interim Finding Report The initial document which contains a comprehensive listing of all findings discovered during an ORR.

Iine organization is that unbroken chain of conmand which extends from the secretary through the Onder secretary, to the Program senior Officials (PSO), who set program policy and plans and develop assigned programs, to the field organization managers who are responsible to the PSO for execution of these programs, to the contractors who execute the programs. Environment, safety and health are integral parts of these programs.

Minor Change is a change which does not significantly aiter the capability, capacity or mode of the operation.

Muclear Facility is a facility whose operations involve radioactive materials in such form and quantity that a significant muclear hazard potentially exists to the enployees or the general public. Included are facilities that: (1) produce, process, or store radioactive liquid or solid waste, fissionable materials, or tritium; (2) conduct separations operations; (3) conduct irradiated materials inspection, fuel fabrication, decontamination, or recovery operations; (4) conduct fuel enrichment operations; or (5) conduct enviromental remediation or waste management activities involving radioactive materials. Incidental use of radioactive materials in a facility operation (e.g., check sources, radioactive sources, and $x$ ray machines) does not necessarily require the facility to be included in this definition.

Normal Safety control Review is an internal review by project required ES\&H functions. This level of review is related to low or negligible hazard conditions, minor changes, or temporary limitations of operations.

Operational Readiness Evaluation (ORE) DOE pre-restart/start up evaluation of activities undertaisen by the contractor or line management, including the ORR, to ensure safety of facility operations after restart/start up.

operational Readiness Review (ORR) is a structured method for determining that an activity is ready to operate including, as a minimm, review of the readiness of the plant, personnel, hardware and procedures. The review must be current and comprehensive and determines compliance with ES\&H orders. 
Operational readiness Review Execution Plan Me procedures which the operating organization uses to initiate, conduct, and closeout a specific ORR.

Goerational Readiness Review Program Plan A plan, developed by the operating organization, which describes the way ORRs will be concucted and how they are integrated into the organizational managenent systen.

gperational Safety Requirements (OSRS) have been replaced by Technical Safety Requirements (ISR). See definition below.

process is a system or series of contimus or regularly occurring actions taking place in a predetermined or planned manner.

Program Senior official (PSO) is a senior outlay program manager and includes the Assistant Secretaries for Conservation and Renewable Energy, Defense Programs, Fossil Energy, and Nuclear Energy, the Directors of Nergy Research, Civilian Radioactive Maste Management, New Production Reactors, and Environmental Restoration and Faste Management.

Quality Assurance consists of all those planned and systematic actions necessary to provide adequate confidence that a structure, system, or component will perform satisfactorily in use, or that products or services provided will fulfill requirements.

Readiness to Proceed Memorandum A formal memoranchm, subiritted to the DOE by a contractor or other operating entity, declaring an activity to be operationally ready.

Restart is an action that resmes operations after a temporary cessation, caused by events other than normal. operations. A restart requires an authorization action to resume facility program work.

Risk, eithier qualitatively or quantitatively, expresses possible loss by considering the probability and consequences or uncertainties of an undesirable event.

Safety Analysis Report (SAR) is a report prequared in accordance with DOE Order 5481.1B/AL Order 5481.1B and DOE Order 5480.23, which sumarizes the safety analyses performed to evaluate the effectiveness of the measures taken to control the hazards associated with a

facility, process, operation, or system. The SAR also defines minimm safety requirements for operation of the facility, process, operation, or system. A safety analysis report is designated as final when it is based on final design information. Otherwise, it is designated as preliminary (DOE 6430.1A).

Safety Class Items are those systems, components, and structures with the following characteristics:

a. Those whose failure would produce exposiure consequences that would exceed the existing guidelines at the point of maximm exposure; 
b. Those required to maintain operating parameters within the safety limits specified in the operational safety requirements (TSRs) curing normal operations and anticipated operational occurrences;

c. Those required for muclear criticality safety;

d. Those required to monitor the release of radioactive materials to the enviroment during and after a design basis accident;

e. Those required to achieve and maintain the facility in a safe shutdown condition; and

f. Those that control the safety class itens described above.

Safety Assessment (SA) is a brief evaluation and Iisk analysis of a facility/operation to determine its level of risk and the need for a SAR.

Smutdown is the condition in which a facility ceases operations for which the facility was being operated, i.e. program work ceases.

Significant modification Any modification that has the potential for exceeding the safety envelope of the authorization basis for the facility.

start is the initial use of new facilities, systems, operations, or .processes. A start requires an authorization action to commence facility program work.

Summary Management Report A report containing the validated lists of category $A$ and $B$ findings and a description of the methods used to track their closeout.

System is a cambination of several pieces of equipment integrated to perform a specific function, and have the potential for significant impact on the enviroment, safety, or health of employees or the public. Examples include: radioactive waste disposal systens, hazardous material disposal systems and transportation systems.

Technical Safety Requirements (TSRs) Notice of Proposed Rulemaking 10 CFR Part 830.320 sets forth the requirements for the scope, format, and technical content of the Technical safety Requirements, which subsumes the Technical specifications used for muclear reactors and the operational safety Requirements used for non reactor muclear facilities. TSRs are to be derived from facility-specific safety analyses. 
Unreviewed Safety question (USO) A proposed change, test, or exper iment shall be deemed to involve an unreviewed safety question if:

a. The probability of occurrence or the consequence of an accident or malfunction of equipment important to safety evaluated previously by safety analyses may be increased; or

b. A possibility for an accident or malfunction of a different type than any evaluated previously by safety analyses may be created; or

c. The safety margins, as defined for any technical specification or the operational safety requirement, are significantly reduced.

In this definition, 'proposed change' includes, but is not limited to: incidents, analyses, modifications, prexesses, systems and/or components, and operations which indicate an inadequacy of previous analyses or a significant recuction in safety margins. Resolution of a USO may lead to revisions of SAR and an authorization action to proceed. The restart autbority may require an ORR as part of the basis for authorization to proceed. 


\section{Acroniyms}

The acronyms in the following section for frequently used in the develogment of ORRs. Persons developing the ORR program plan and/or concucting ORRs should be familiar with them. In general, these acronyms are consistent with existing DOE publications.

DAO - DOE Dayton Area OfficeD\&D - Decomissioning and Decontamination ES\&H - Envirormental Safety and Health

FRR - DOE Facility Representative Review

IOO - Iimiting Condition for Operations

MORr - Management Oversight and Risk Tree

ORE - Operational Readiness Bvaluation

ORR - Operational Readiness Review

OSTRA - Occupational safety and Health Administration

OSR - Occupational Safety Requirements

PSO - Program Senior official

$Q A$ - Quality Assurance

QC - Quality Control

RA - Risk Analysis

RR - Readiness Review

SA - Safety Assessment

SAR - Safety Analysis Report

SSDC - Safety System Development center

TSR - Technical Safety Requirements

USQ - Unreviewed Safety Questions

WMOSD - Waste Management and Operational surety Division 
APPENDIX D 
CONDDCT OF OEFRAIIONIS

SEIF-ASSESSMENTI

SURVEY

REV. 2

Note: Where this survey conflicts with MD-10361, Issue 2, the survey takes precedence. 



\section{INSTROCIIONS}

1. Complete the "Conduct of Operations Baseline Self-Assessment Fon"

2. Using the "Facility Hazand Classification" and the "Concuct of Operations Self-Assessment survey" form, answer the applicability statement for each chapter. Where the chapter applies to your facility, answer the B-level questions. If the answer to the applicability statement is "noll, skip the B-level questions and proceed to the next chapter. Reep in mind that the answers you provide should reflect the collective status of all rocms comprising your "facility".

NOIIE: Compliance Determination: The following 1 through 4 scale is to be used in answering the B-level questions. Circle the number which best reflects your facilities' level of conformance.

$1=10$ (Not in conformance)

2 = ION DEGREE of conformance

3 = HIIGI DEGREE of conformance

$4=$ yes (In conformance)

3. Retain a copy of the self-assessment for use in determining necessary remedial actions for your facility. Additionally, a completed copy of the self-assessment should be provided to M. P. Shade, Building 40. 
CONDUCT OF OFHRAMITINS

BASFTINE SETF-ASSESSMIFII FORM

DAITE:

FACIIIIY NAME:

IACIHIIII IOCAIION (BRDG./ROOM(S) (See Note \#1)

FACIIITY HARARD CTASSIFICAIION (HIIT, MODERATIE, IOW) (See Note \#2)

STARE OF THIE SUPHRVISOR RESPCAISIBTS

FOR THE FACIIIITY

AFPROVED BY: (Responsible senior Manager)

NOII \#1: The decision as to which rocms comprise a particular facility is left to the juagement of the Iine organizations. However, when making that decision the following sbould be considered:

There should be a logical rationale for the grouping of rocms comprising the facility (e.g. common purpose).

-If both Iow and moderate hazard rooms make up a "facility", then from a conduct of pperaticons (0)0) viewpoint the facility will be considered moderate haviard and the low harard operations must conform to the moderate hazard 00 requirements.

- In case where the same operating personnel operate both low and moderate hazard facilities it may be appropriate to operate both at the moderate harard level to avoid confusion.

-It is recoumended that a facility not be divided into increments smaller than rocm level. However, if there is good, defensible rationale for sub-dividing a rocm into Imltiple facilities, that will be the decision of the senior Manager responsible for the farility.

NOIE \#2: If the "facility" is comprised of more than one rocm, all rocms shorld be identified. If those rocms are of differrent hanard classification levels, then the fasility will be considered to be at the highest classification and the self-assessment shoild be carried out at that level. 
CRPPIER I operations Onganization and Administration

Ievel "gu" Conditions Requiring Camliance Fith This Chapter

Yes No 1. The facility is high, moderate or low hazard.

Yes no 2. The facility is standard incustrial/no hazard, but Management has elected to operate it consistent with a higher hazard classification.

If either of the above statements are true (Yes), proceed to the "G"' level questions. If neither of the statementsine status of compliance."

18. Determine status of compliance

Answer questions for your hazard category. Ieave blank any questions in this section designated for your category that you consider not applicable; a short narrative explaining why that question is not applicable should be provided.

1234 1a. Do you have sop's, procecures, or instructions for your hazardous operations? (H,M,I)

Note: Written procechures are required whenever the operation involves the amount of hazardous (radicactive or energetic) material that is enough to involve a high, moderate, or low hazard condition. If the process being used has no material present at hazard levels, but is to be used for a high, moderate or low hazard, or could be inadvertently connected to quantities of material at higher hazard levels, such as by opening a combination of valves, the operation would be treated as if the hazard were present and would require a written procecture.

1234 1b. Have these procecures been reviewed and approved in accordance with Policy/Procedure 1018 "Revies of operational Procedures by senior Safety Review camittees"? ( $\mathrm{H}, \mathrm{M}, \mathrm{L})$ 


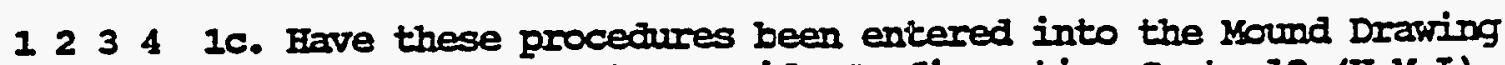
control system to provide Configuration Control? (H,M,I)

1234 2. Do you make periodic (i.e. monthly) inspections of your operating activity in accordance with P/P 1012 inanagement Awareness Irogram" and MD-10286 "Msound Safety and Hygiene Mamial," section J, and do you keep records of same? $(H, M, I)$

1234 3a. Are the responsibilities and accountability of operating personnel defined within their Job Evaluation Document (JiD), and/or within appropriate administrative procedures? (H,M,I)

1234 3b. Do You follow P/P 7102 "Salaried Emoloyee Performance Plaming and Evaluation" for the setting of objectives and goals, and maintaining accountability for performance? (I, M, L)

1234 4. Does management pramulgate goals and objectives, and does a program exist to monitor progress toward the achievement of those goals and objectives. (H,M,I) 
1234 5. Are facility-specific training programs established and currentiy being used to train operating personnel, supervisors, and managers performing hazardous operations? ( $\mathrm{H}, \mathrm{M})$

1234 6a. Has management provided sufficient resources to complete assigned tasks witbout the excessive use of overtime. $(H, M)$

1234 b. Has a long-range ( 3 year) staffing plan been developed that anticipates losses of personnel? (H,M)

NOIE: The long range staffing plan is required for positions in which extensive training/certification is necessary to providing qualified replacements. This is not a budget document, its intent is to plan for appropriately trained replacement personnel. The staffing plan should list the positions requiring extensive training/certification, the name of the incumbent, logical backup(s) and a training schecule for the backop(s). If backup personnel are already qualified, then it should be so indicated on the plan. If there are no positions requiring extensive training or certification the plan should state, IN/A no positions requiring extensive training or certification". 
CONDOCI OF OPERAIIONS SHF-ASSFSSMENI SURVEY.

CFAPIHR II Shift Routines and oparating Practices

2A.

Appilicability

Yes 15o 1. Could undetected equipment failure pose a significant harard to personnel, the public or the enviroment? This includes, but is not limited to, damage to primary or secondary enviromental monitoring. systems and/or systems supporting ICO!S (as defined in the SAR) sufficient to prevent their proper functioning.

If the answer to the above question is "res", the chapter is applicable. rowing the details of your operation continue to section 28 to "Determine status of compliancel". If the answer to the above question is; "nol", proceed to the next chapter.

2B. Determine status of Compliance

Answer questions for your Hazard Category. Ieave blank any questions in this section designated for your category that you consider not applicable; a short narrative explaining why that question is not applicable should be provided.

1234 1. Have hazards (energetic or mulear) in the work place been properIy identified and appropriate safety training of cperating personnel completed? (H,M,I)

12342 . Have procedures been established which require operator inspection tolurs and routine monitoring and recording of equipment operating parameters? The records related to these touss, monitoring and recording activities are known as "round sheets". $(\mathbf{H}, \mathbf{M})$

Hote: This is directed at equipment/systems in which undetected failure could pose a harard to personnel, the public and/or the envirosment. Therefore, procecurres and records used to implement Policy 1016, "ponitoring Iimiting conditions of operations" are an exple of this practice.

$$
-6-
$$


1234 3. Does the operations supervisor authorize the operation of all equipment deened part of the operating activity and is he/she pramtly notified of changes in the facility or equipment status.

1234 4. Bave procedures been prepared which provide for the review, trend analysis and retention of "round sheets'? (H,M)

1234 5. Are operating personnel instructed to believe their indicators and react conservatively to unusual or abnormal events? ( $\mathrm{H}, \mathrm{M}, \mathrm{I})$

1234 6. Has clear direction been provided to operating personnel regarding notification of the operations supervisor when unanticipated occurrences, operating difficulties, etc. are encountered? ( $\mathrm{K}, \mathrm{M})$

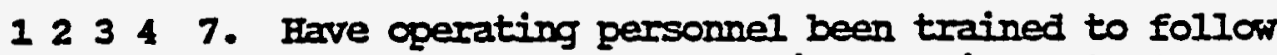
posted personnel protection requirements.? (H,M,I) 
3A. Applicability

Yes 150 1. Is there a central location (control rocm) containing operating controls from which processes and/or remote facility equipment are controlled?

Hote: This chapter does not apply to operating controls which are on or immediately adjacent to the facility equipment. The requirements of this chapter only apply to a control rocm.

If the answer to the above question is "res", the chapter is applicable. Inowing the details of your operation contimu to section 3B to "Determine status of compliance". If the answer to the above question is "no", proceed to the nest chapter.

38. Determine status of compliance

Answer questions for your Hazard Cairegory. Leave blank any questions in this section designated for your category that you consider not applicable; a short narrative explaining why that question is not applicable should be provided.

1234 1. Has management issued guidelines for the professional conduct of activities within the control rocm? $(\mathrm{H}, \mathrm{M}, \mathrm{I})$

123.4 2. Are operating personnel in the control area protected from distraction caused by other activities ongoing within the facility? (E,M) 
$\begin{array}{lllll}1 & 2 & 3 & 4 & 3\end{array}$. Is access to the control area Iimited to those personnel having official business in the control rocm? Has management provided a listing of who should be acinitted or provided other control (e.g. card entry, lock, etc.) which assure proper access control. (II)

1234 4. Are operating personnel in the control rocm alert and attentive to the controls? (H,M)

1234 5. Are operating personnel aware of in the importance of monitoring the control rocm panels? (H,M)

1234 6. Is operation of control rocm equipment limited to qualified operating personnel? (H,M) 


\section{CONDOCT OF OFHRAIIONS SELF-ASSESSMIANT SURVEY}

CARAPLER IV Commmications

4A. Applicability

Yes 10 1. Does your organization use audible conmmications systems (borns, bells, public address systems, phones, radios, etc.) to transmit operating or emergency information lother than fire alams) within the facility.

If the answer to the above question is ryss", the chapter is applicable. Fonowing the details of your operation continue to section $4 B$ to "Determine status of Compliance". If the answer to the above question is "Wo', proceed to the nest chapter.

4B. Determine Status of compliance

Answer questions for your Harard Category. Ieave blank any questions in this section designated, for your category that you consider not applicable: a short narrative explaining why that question is not applicable should be provided.

1234 1a. Are only established and tested systems, authorized for use by management, used for commonicating emergency information. Authorized and tested systems include the plant FA, Iadio system, fire alam system, klaxton horns, local alarms, health physics, enviromental, etc.? (H,M,L)

1234 1b. Are personnel trained in the proper response to energency commoications? ( $\mathrm{H}, \mathrm{M}, \mathrm{I})$ 
1234 2. Do emergency FA and radio cammications override all other PA and radio commmications in the facility? $(\mathrm{H}, \mathrm{M}, \mathrm{I})$

Note: If only the plant PA and radio commonications systems are used, the answer to the above question is "4" ("yes").

1234 3. Do procedures stress clear concise oral instructions and commmications? Is there an approved list of abbreviations and acronyms? Are instructions involving the operation of critical safety equipment repeated back to the initiator by the receiver? (H)

1234 4. Is commications equipment maintained to ensure that it is available when needed? (H,M,I)

Note: If only the authorized systems identified in 12. above are used, the answer to the above question is "yil ("yes"). 
CONDUCT OF OFERAHIONS SHTF-ASSEISSMFNI SURVEY

CARPIHR $\nabla$ control of on-The-Job Training

5A. Applicability

Yes 150 1. Is on-the-job training part of the formal training program required to qualify operating personnel for your facility.

If the answer to the above question is "res", the chapter is applicable. Inowing the details of your operation contime to

- section 5B to "Determine status of calpliance". If the answer to the above question is "no", proceed to the next chapter.

5B. Determine status of compliance

Answer questions for your Hazard Category. Leave blank any questions in this section designated for your category that you consider not applicable; a short narrative explaining why that question is not applicable should be provided.

1234 1. Is on-the-job training performed in accordance with system Manual 112, "Molmd Central Training Procedures", Procedure No. 01, "Certification of Instructors" and Procedure 150. 03, "Conduct of on-The-Job Training". (E, $\left.M, I_{2}\right)$

12342 . Have those personnel who provide arT completed the Hound or instructors course? (H,M,I)

1234 3. Have OF instructors submitted their "Qualification carall to central Training? (H,M,I) 


\section{CONDOCT OF OFHRATIONS SETF-ASSESSMENT SURVEY \\ CFAPIER VI Investigation of Alonomal Events}

6A. Applicability

Yes 110 1. Is there a possibility that your facility could experience an abormal event that is Ieportable to DOE?

If the answer to the above question is "rysil, the chapter is applicable. Frowing the details of your operation continue to section 63 to "Determine status of compliancel. If the answer to the above question is ino", proceed to the next chapter.

6B. Determine status of compliance

Answer questions for your Hazand Category. Ieave blank any questions in this section designated for your category that you consider not applicable; a short narrative explaining why that question is not applicable should be provided.

1234 1. Are investigations performed in accordance with MD-10286, "Wound Safety and Hygiene Manual," section R.2? (H, M, I)

1234 2. Have you (the supervisor responsible for the potentially bazardous activity) completed root cause analysis training? (H,M,I) 
7A. Applicability

Yes 150 1. Is your operating activity capable of intermal or external failures, off-normal occurrences, (e. procecurral violations), umusual occurrences (e. failure of sarfety equipment of systens) or emergencies that coilld be reportable under the requirements of DOE order 5000.3A, "Oscurrence Reporting Programin?

If the answer to the above question if "ros", the chapter is applicable. roowing the details of your operation contime to section 7B to "Determine status of campliancel. If the answer to the above question is "mo', proceed to the next chapter.

7B. Determine status of compliance

Answer questions for your Hazard Category. Leave blank any questions in this section designated for your category that you consider not applicable; a short narrative explaining why that question is not applicable should bel provided.

1234 1. Are notifications completed in accordance with the requirements and procedures established in the "Mound Plant Implementation of: DOE Order 5000.3A, Occurrence Reporting and Processing of Operations Information"? (H, K, I)

1234 2. Has adequate guidance been provided on what is to be reported and how rapidily reporting is required? 
CFAPIER VIII Control of Equipment and system status

8A. Applicability

Yes 10 1. Does the safety basis for your operating activity include primary environmental monitoring (i.e. Class A) equipment; and or secondary enviromental monitoring equipment and/or equipment used in support of IOO's (i.e. Class B)? These systems are defined within the SAR. If a SAR is not available, have ICO's been established for your operating activity? Further definition of class A and B equipment is contained within the "EGSG Hound operations Manual", MD-10361.

If the answer to either of the above question is "rss", the chapter is applicable. Inowing the details of your operation continue to section 88 to "Deternine status of compliance". If the answer to the above question is "nol', proceed to the next chapter.

8B. Determine Status of campliance

Answer questions for your Hazard Category. Ieave blank any questions in this section designated for your category that you. consider not applicable; a short narrative explaining why that question is not applicable shourd be provided.

1234 1a. Has management docmented which equipment is Class A and/or class $B$ within your facility?. If the answer to question \#12. was "I" ("MN"I) - go to Chapter 9. $(\mathbf{H}, \mathrm{M}, \mathrm{I})$

1234 1b. Are only appropriately trained personnel permitted to operate class A and/or B equipment? (H,M,I)

1234 2. Are personnel (e.g. maintenance personnel) working in the facility required to interface with operating personnel prior to:

-starting/stopping Class A and/or B equipment -Taking class A and/or B equipment out of service

for maintenance

-Restoring equipment to service after maintenance? (H, $\mathcal{H}, I)$ 
1234 3a. Is class $A$ and with Policy 1016 monitoring rimiting conditions for operations?" (I, M,I)

1234 3b. Is the status of class A and/or B eugipment controlled by use of lcakout/tagout procedures identified in Chapter IX? (H,M,I)

1234 4. Are procedures in place to control the placement, removal, and periodic jeview of temporary modification such as electrical jumpers, lifted leads, pipe blanks, etc? Which effect class $A$ and/or Class B equipment? ( $H, M, I)$

1234 5a. Are proposed changes to Class A and/or B equipment reviewed and approved loy the responsible supervisor and the Independent safety Revien Coordinator?

$(\mathbf{H}, \mathbf{M}, \mathrm{I})$

1234 5b. Then changes involve building camon Class A and/or B equipment, does the Building Manager also approve the change? (H,H,I)

1234 5c. Is the Euilding Manager made aware of all planned changes to Class A and/or B equipment? (H,M,I) 
1234 6. Are there adninistrative controls in place to control the performance of maintenance (incluaing post-maintenance testing) on Class $A$ and facility equipment. (H,M,I)

12347 . Are controlled documents (technical mamals, drawings, etc.) available to operating and maintemance personnel when performing maintenance on Class A and/or B safety equipment? (H,M,I) 


\section{CONDUCI OF OPFRATIONS SHLF-ASSESSMIFNI SURVEY}

CHAPIIER IX Iockouts/Tagouts

9A. Applicability

Yes No 1. Is there a potential for personnel injury, or equipment damage curing equipment operation, servicing, maintenance or modification activities due to an inadvertent equipment activation?

If the answer to the above question is "rrss", the chapter is applicable. Frowing the details of your operation contimie to section 9B to "Determine status of compliancel. If the answer to the above question is "Won", proceed to the next chapter.

9B. Determine Status of Compliance

Answer questions for your Harard category. Leave blank any questions in this section desicnated for your category that you consider not applicable; a short narrative explaining why that question is not applicable should be provided.

1234 1. Are the requirements and procectures identified in MD-10286, "nsound Safety and Hygiene Mamual," related to "Iockout/Tagout" implemented in your operations where appropriate? (H,M,I)

1234 2a. Have all your personnel who perform lockout/tagout received "Puthorized Iockout/Tagout training". (H,M,I)

1234 2b. Have the remainder of your personnel received "Affected Iockout/Tagoult training"? (H,M,I) 
10A. Applicability

Yes No 1. Do your employees perform operations on safety related and/or non safety related components/equipment/systems where an inappropriate positioning of a component could lead to facility shutdown, challenges to safety related systems or other undesirable effects on facility safety and reliability?

If the answer to the above question is "rys", the chapter is applicable. roowing the details of your operation continue to section 10B to "Determine status of Compliancel. If the answer to the above question is 'no', proceed to the next chapter.

10B. Determine Status of Compliance

Answer questions for your Hazard Category. Ieave blank any questions in this section designated for your category that you consider not applicable; a short narrative explaining why that question is not applicable should be provided.

1234 1. Has management identified which class A and/or B equipment requires independent verification and when? (H, M, L)

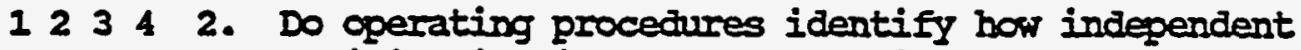
verification is to be accomplished, are operating personnel periodically monitored by line management to verify compliance and are the verifications cocumented? (H, M, I)\}

$\begin{array}{lllll}1 & 2 & 3 & 4 & 3\end{array}$. Do you have a documented training program for persons performing the independent verification fumction? $(\mathrm{H}, \mathrm{H}, \mathrm{I})$ 


\section{CONDUCT OF OPERATIONS SETF-ASSESSMDHVT SURVEY \\ CFAPIER XI Iogkeeping}

11A. Applicability

Yes 30

This chapter applies to all high, moderate, and low havard facilities.

118. Determine status of Compliance

Answer questions for your Hazard Category. Ieave blank any questions in this section designated for your category that you consider not applicable; a short narrative explaining why that question is not applicable sbould be provided.

1234 la. Is a log maintained within your facility? (H, $M, I)$

1234 16. Are entries in the log: made by the close of the operating period? (H,M,I)

1234 2. Does the log, for the purpose of recording deviations Iron nonmal expected speration, as a minimin, contain a description of the event, time, date, location, action taken to return the cperation to normal, and identification of the individual making the log entry? ( $\mathrm{H}, \mathrm{M}, \mathrm{I})$

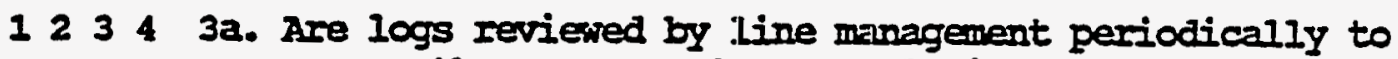
ensure they are complete and legible? (H,M,I) 
1234 3b. Are line managements reviews of logs documented? $(\mathrm{H}, \mathrm{M}, \mathrm{I})$

Note: This may be accomplished by making an entry in the logbook indicating that the review occurred or reoording the fact that the logibook was reviewed in the supervisors management awareness records.

1234 4. Are aministrative controls established to ensure that operating logs are readily available for a sufficient period of time to allow for the transfer of information among operators? (H,M)

1234 5. Can events be reconstructed from a combination of data maintained in the 109 , recorded data (e.g. strip charts, etc.) and operating personnel debriefing? $(\mathrm{H}, \mathrm{M}, \mathrm{I})$ 
12A. Applicability

Yes 210 1. Is your facility high, moderate or low hazard and is responsibility for operations turned over from one operating person to another in the midale of an operation?

Note: This chapter relates to activities in which there is a formal transfer of responsibility between operators of orgoing processes, when information on the status of the process is not readily available and when the process is not capable of Imning safely without oversight.

If the answer to the above question is "ryzs", the chapter is applicable. Inowing the details of your operation continue to section 22B to "Determine status of compliancel". If the answer to the above question is "nod", proceed to the next chapter.

12B. Determine Status of Campliance

Answer questions for your Hazard Category. Leave blank any questions in this section designatel for your category that you consider not applicabie; instead, write a short justification below the question.

-1234 1a. Do you have a turnover checklist(s) equivalent to that identified in 60 below to guide the turnover process? (H,M)

1234 1b. Is the turnover documented in the operating log, on the turnover cheaklist or in same other record? $(\mathbf{E}, \mathbf{M})$

12334 2. Is a review of logs arid records part of the turnover process and can facili.ty status (including the status of safety devices) be ascertained by reviewing facility logs and reorsds? (H,M) 
1234 3. Is a walkdown of the control area (control rocm) panels part of the turnover of operations. responsibility? (H,M)

1234 4. Do you require that a camplete verbal briefing be given to the oncoming responsible person before he/she assumes responsibility for operations? (E,M,I)

1234 5. If a supervisory change occurs during a shift, does the replacement supervisor receive a turnover briefing prior to assuming responsibility of the operation? (II)

1234 6a. Have provisions been made to deal with umplanned turnovers (e.g. due to illness, etc.)? (H,M)

1234 6b. Are umlanned turnovers guided by a checklist which includes an identification of the process being performed, where the current operator is in the process, the status of equipment, notification of the supervisor that a change of operators has occurred and answering specific questions of. the incoming operator? (H,M)

1234 6c. Is a record of the turnover made in the operating log or documented in same other record? (H,M) 
CARPIFR XIII Operations Aspects of Facility Chemistry and unique Processes

13A. Applicability

Yes 10 1. Does your facility utilize chemicals or hazardous materials in a process which, if not properly controlled, could be a hazand to personnel or the enviroment, and/or lead to accelerated degradation of equipment or systems?

Note: The primary abjective of this chapter is to insure that operating personnel are knowledgeable of the systems with which they are working. Their required level of knowledge of the chemistry involved, is dependent on the degree of freedon the individual has to exrercise independent juagenent. For example, an operator of a system would not typically require the same level of knowledge as the individual who establishes the systems operating parameters. However, the operator should understand why it is important to remain within the established parameters and the consequences of exceeding those parameters.

If the answer to the above question is ryris", the chapter is applicable. Foowing the details of your cperation continue to section 13B to "Determine status of campliance". If the answer to the above question is "no", write a brief justification to explain why the chapter is not applicable and proceed to the next chapter.

23B.

Determine Status of compliance

Answer questions for your Hazard Category. Ieave blank any questions in this section designated for your category that you consider not aplicable; a short nanrative explaining why that question is not applicable should be provided.

1234 1a. Are operating personnel familiar with all processes within the operating astivity for which they are responsible? (H,M,I)

1234 1b. Do you have in central training auditable training records which show that each facility person was trained? (H,M,I) 
1234 2. Is each operating person's responsibility with respect to process control defined in their procedures? (H,M)

1234 3. Are your operating personnel knowledgeable about aspects of facility processes and safety that they can recognize abnormal indicators and commence corrective actions? (H,M) 
14A. Applicability

Yes 150 1. Does management need to bave a formal metbod to apprise operating personnel of changes to written procecures and other documents which impact their work practices?

If the answer to the above question is "res", the chapter is applicable. Frowing the details of your operation contimue to section 14 to 'Determine status of Compliancell. If the answer to the above question is "no", proceed to the next chapter.

14B. Determine status of Campliance

Answer questions for your Hazard Caisegory. Ieave blank any questions in this section designated for your category that you consider not applicable; a sbort narrative explaining why that question is not applicable should be provided.

1234 1a. Bas a required reading file been established which includes procedure chainges (i.e. those procectures that are not PI controlled) lessons learned, changes to KSDS sheets and changes to operational safety requirements? (H, $\mathrm{M}, \mathrm{I})$

1234 1b. Does each document. in the file have a sign-off sheet? (H,M,I)

1.234 1c. Is the reading file accessible to all operating personnel? (B,M,I) 
$\begin{array}{llll}1 & 2 & 3 & 4\end{array}$. Is a periodic check of the reading file perfonmed to ensure that operating personnel are completing reading as required and is the check documented? $(\mathrm{H}, \mathrm{M}, \mathrm{I})$

1234 3. Are key personnel required to review the reading file prior to assuming responsibility for the operation following any absence of greater than 24 bours of operating time?

(B) 
CFRPIIFR XV Timely Orders to Operating Personnel

15A. Applicability

Yes 30 1. Does (or should) management periodically provide short-term information to operating personuel such as special operations to be performed, data to be gathered, work priorities, changes to scheculled activities, etc.?

If the answer to the above question is myss", the chapter is applicable. Roowing the details of your ogeration contimue to section 158 to "Determine status of Bompliance". If the answer to the above question is "no", proceed to the next chapter.

15B. Determine status of compliance

Answer questions for your Hazard Category. Ieave blank any questions in this section designated for your category that you consider not applicable; a short narrative explaining why that question is not applicable should be provided.

1234 1. Is short-term information commmicated either verbally or in writing to operating personnel regarding work priority, activities to be performed wring the next 24 hours and other information to assist the operators in planning and prioritizing their daily work? (E,M,I)

1234 2. Does management inform persoinnel of changes to instructions. in a timel.y manner? (H,M)

1234 3. Is a procedure (methodology) in place to ensure that long-term instructions are incorporated into appropriate policy dociments or procecures? (H,M) 


\section{A. Axplicability}

Yes No 1. Does your facility possess and use systems and equipment in operations involving energetic or miclear materials that must be operated in accordance with mamufacturers' or engineering instructions?

Yes No 2. Do you have systems/equipment that may be operated by several different people in operations involving energetic or nuclear meterials, chring the course of a work week?

Yes 210 3. Is it important to the safe and reliable operation of the facility that all operators operate systems/equipment in operations involving energetic or muclear material by the same procecures?

If the answer to any of the above questions is "Yes", the chapter is applicable. Fnowing the details of your operation contime to section 16B to "Detemine status of Compliance". If the answer to the above question of 'No', write a brief justification to explain why the chapter is not applicable and proceed to the next chapter.

16B. Detemine status of campliance

Answer questions for your Hazard Category. Ieave blank any questions in this section designated for your category that you consider not applicable; a short narrative explaining why that question is not applicable sbould be provided.

1234 1a. Do procectures in your facility conform to the requirements of MD-10001, "A Guide for miting and Publishing Technical Mamuals", specifically regarding their review by the appropriate SOC comittee and approval by the responsible senior Nanager? (H,M,I)

1231 1b. Are operating personnel aware of, and adhere to the requirements of R/P 1019 "Procedure campliancel? (H,M,I) 
1234 2. Have operating procedures been developed to assure that the facility is operated within its design limits? (H,M,I)

1234 3. Is the wording of operating procedures clear and concise as required by $\mathrm{MD}-10001$, "M Guide for writing and Publishing Technical Mamals'l? (H,M,I)

1234 4. Are procecures sufficiently detailed to permit trained operating personnel to properly complete the required task without supervision? (H,M,I)

1234 5. Are operating procedures consistent with the current operating configuration? (H,M,I) 


\section{CRAPIIFR XVII Personnel Operating Aid Posting}

17A. Applicability

Yes No 1. Do operating personnel use "Operator Aids" (information posted for personnel use) to provide useful information to them while performing their duties?

NOTE:

An "Operator Aid" is a portion of a procedure or other official document that is posted on or near equipment for an operator to use when operating the equipment. These are distinct from warning and havard signs and tags such as required by OSHA, ANSI or other standards. Mamufacturer labels or tags are not considered operator aids. Reep in mind that an operator aid relates to the operation of equipment. For example, assume that an English/Metric conversion chart is posted at a piece of equipment for a technician to use while operating the equipment - this is considered an operator aid. An identical conversion chart is posted at the technician's desk to assist him in record keeping - this is not considered an operator aid. Typically, administrative postings, identification labels, etc., would not be considered an operator aid. Care should be taken when applying any posting to assure that it does not obscure instruments or controls.

If the answer to the above question is ryrs", the chapter is applicable. Rnowing the details of your operation continue to section 17B to "Determine status of compliance". If the answer to the above question is "nol, proceed to the next chapter.

\section{B. Determine status of Compliance}

Answer questions for your Hazard Category. Leave blank any questions in this section designated for your category that you consider not applicable; a short narrative explaining why that question is not applicable should be provided.

1234 1. Has the operations supervisor approved (signed and dated) all operator aids used in the facility? $(\boldsymbol{H}, \mathrm{M}, I)$

12342 . Is a $\log$ of approved operator aids maintained? $(\mathbf{H}, \mathrm{M}, \mathrm{I})$

12331 3. Are operator aids posted so as to avoid the obscuring of instruments or controls? (H,M,I) 
1234 4. Are operator aids used to supplenent procechures rather than being used in place of procedures?

$(\mathrm{H}, \mathrm{M}, \mathrm{I})$

1234 5. During management awareness tours (self-assessments) are operating aids periodically inspected to assure that they have been authorized for use? Have these assessments been docimented? (H,M,I) 
18 Applicability

Yes No 1. Are your operations of such a nature that operating and maintenance personnel need to positively identify which equipment they are to operate, service, and maintain?

If the answer to the above question is "yes", the chapter is applicable. knowing the details of your operation continue to section 18B to "Detemine status of compliance". If the answer to the above question is "no" proceed to the next chapter.

18B. Determine Status of Coupliance

Answer questions for your Hazard Category. Ieave blank any questions in this section designated for your category that you consider not applicable; a short narrative explaining wry that question is not applicable should be provided.

$\begin{array}{llll}1 & 2 & 3 & 4\end{array}$. Is the exposed piping, excluding electrical conduit in your facility labeled in accordance with the following:

-labeled at least once in the room indicating the contents and flow direction

- labeled at intervals of 20 feet on straight rums

- labeled where it enters or leaves a rocm

-labeled where a change of direction of pipe occurs (tees, elbows, branches, etc.)

- labeled at locations where identification would aid operation (valves, pumps, etc.)? (H, M,Is)

1234 2. Is equipment labeling consistent with procedures? $(\mathrm{H}, \mathrm{M}, \mathrm{I})$.

Note: Equipment labeling is appropriate where the use of a specific piece of equipment is required and where the operator could easily confuse which equipment is to be used. 
1234 3. Are equipment labels easily read and placed as near as possible to the equipment to be labeled? (H,M,I)

1234 4. Have operating personnel been informed that it is their responsibility to label equipment within their area when required by 非 above and that engineering maintenance should be notified to perform pipe labeling where it failss to meet the requirements of "I above and to notify maintenance of the need to replace missing or damiged labels? (H,M,I) 
1. Which of the following work place documentation do you have readily available for your facility? (H,M,I)

NOTE: "rieadily available" means that the supervisor, and where appropriate, operating personnel, know where the information is (i.e. they shouldn't have to go search for the information).

Y N a. Organizational Chart Es\&G Nound Organizational Chart)

Y N b. Index of Approved Procechres, sops, COPs, etc.

Y N C. Nanagement Awareness Iog

Y N d. JED for each employee

Y N e. Performance Plan/JRA for each entoloyee

Y N f. Iist of identified hazardous operations/processes in the facility

NA $\Psi$ N g. Training Matrix (employee v.s. required training

NA $Y$ N h. Guidelines for professional conduct (control rocm

- activities only)

NA I N i. File/log of occurrence reports for your facility (i.e. 5000.3A/morning report)

INA $Y$ N $\mathrm{I}$. Iist of class "R" and class "B" equipment

NA $Y$ N K. Iist of equipment and processes requiring independent verification

NA Y N 1. Iist of approved operator aid postings

NA I N m. CogY of completed "conduct of operations Self-Assessment survey"

NA $Y$ N $N$. Iist of approved variances from 000 Program requirements

NA $Y$ i 0 . File of "Required Reading"

NA $Y$ N p. Iog of Deviations from Hormal Expected qperations 
Y N q. Configuration Index for Documents Referenced by $10-10361$

I N I. MD-10001, A Guide for Friting and Publishing Technical Mamals

y I 3. MD-10286, yound Safety and Eryqiene Yamual

Y N t. MD-10361, EGSG Mound Operations Memul

$Y$ I. 1 . kound Plant Implementation Plan for DOE Order 5000.3A

I $N$ v. Mound Administrative Folicy Mamul and kound Administrative Procedure Mamual

I $N$ w. Systems Mamul 112, Moumd Training Plan and Procedures, Procecture 03, Concuct of on-Ihe-Jab Training

2. Which of the following work place documentation do you have readily available in your facility? (H,M)
NA $\mathbf{Y} \mathbb{N}$
a. Index of approved operator inspecition tours
INA $\mathbf{Y}$ N
b. Staffing plan
NA $\mathbf{Y} \mathbb{N}$
c. Operations Turnover checklist 
APPENDIX E 


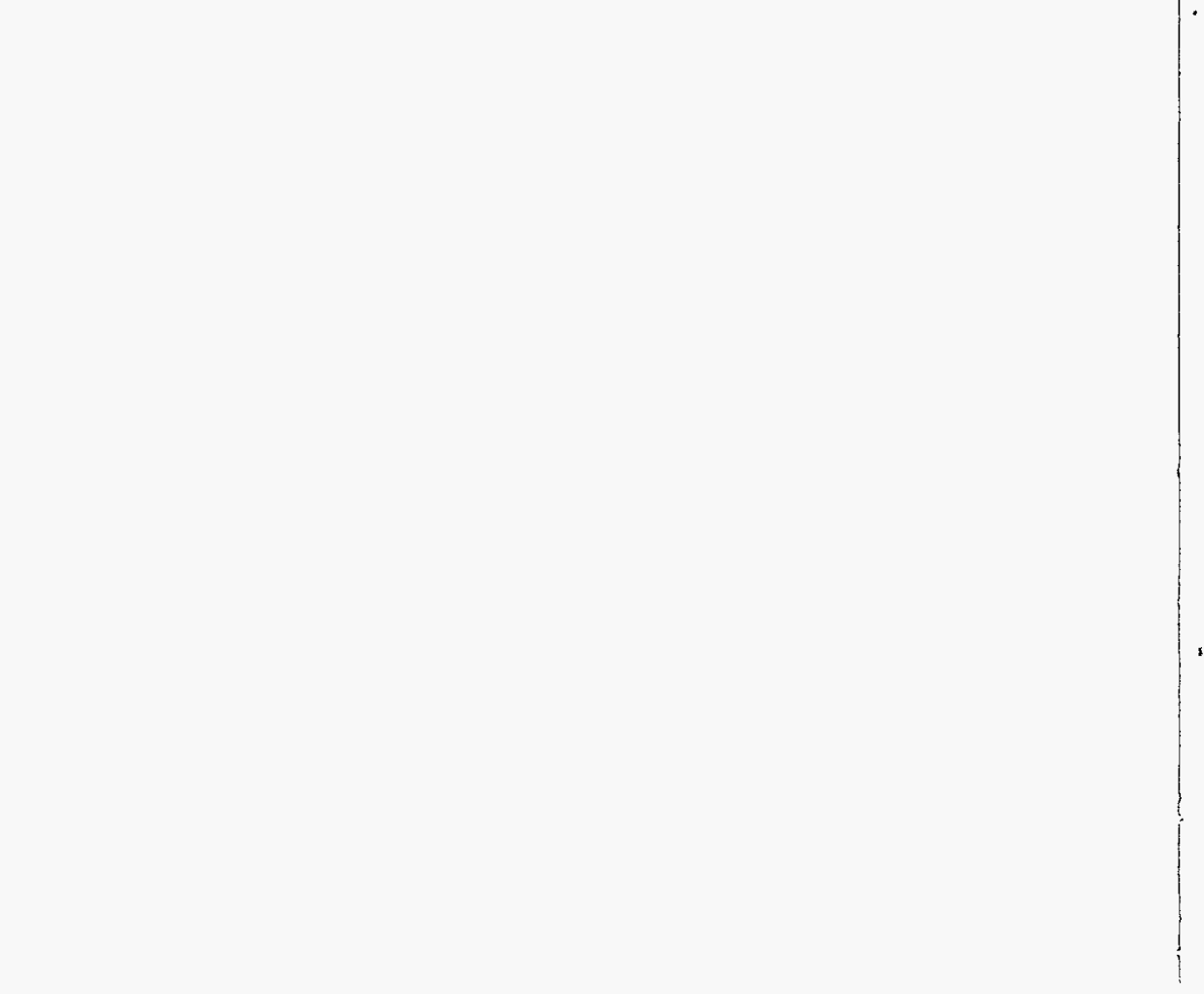


MOUND ES\&H COMMITTEE

CHECKIIST

OPERATIONAL READINESS

The following checklist is to be used to track operational readiness activities for hazardous and non-hazardous projects at Mound.

\section{PROJECT}

DESCRIPTION :

PROJECT IEADER:

SR. MANAGER APPROVAL:

ISRCC CHAIR APPROVAL:
DATE :

DATE :

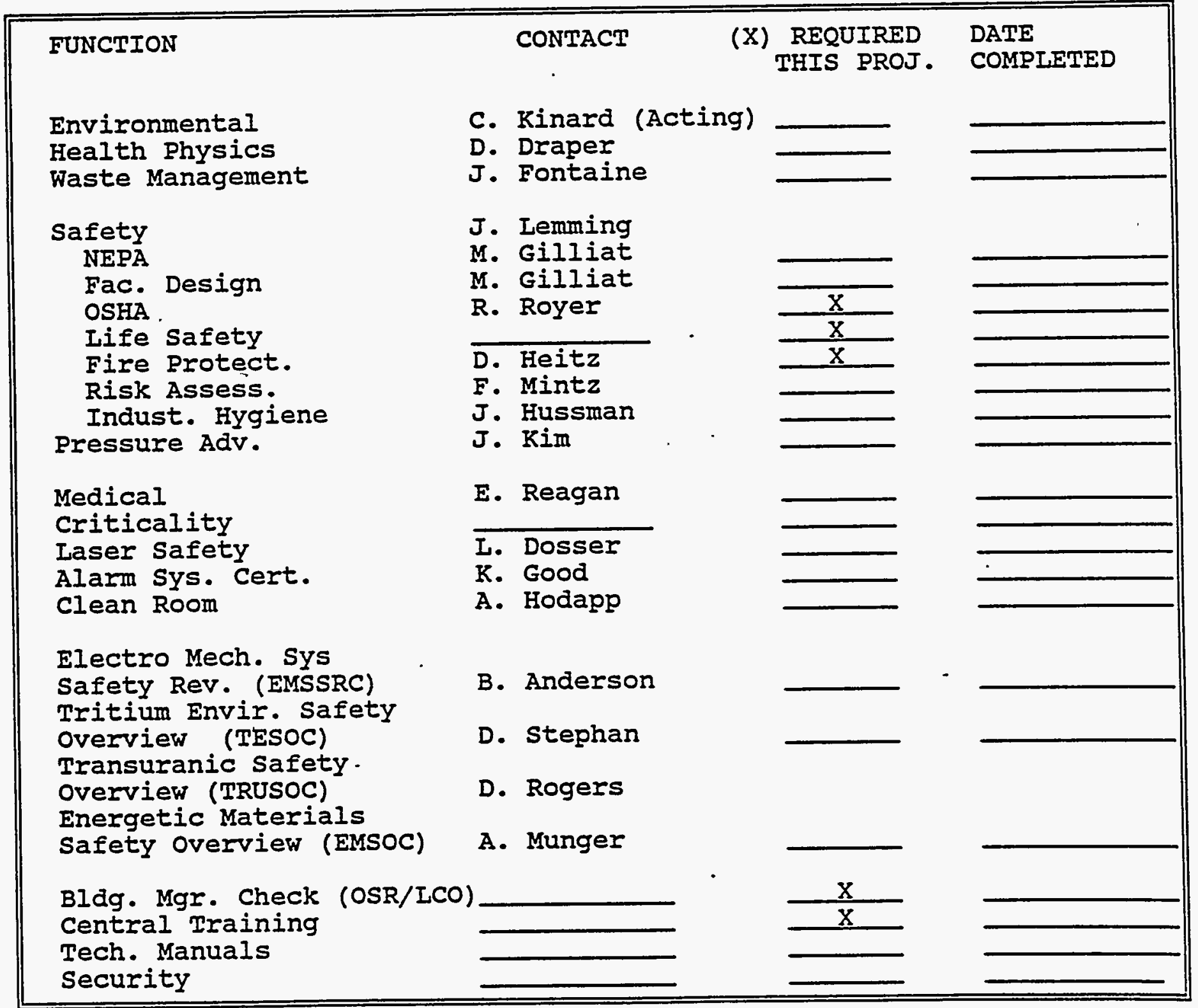




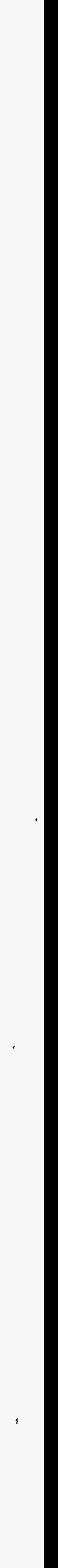


APPENDIX F 
INTEROFFICE CORRESPONDENCE
DFIIS:
July 31, 1991
Ce: H. F. Anderson
T. I. Burtan
TO:
C. N. Iindsay
ERas:
R. E. Vallee'
SUBJECI: Charter for EGEG Contractor
operational Readiness Review (C-ORR)
E. G. Depew
J. J. Eurrly
I. D. Martin
I. A. Foltenann
File
start-up of ST-150, Furction Test station
The purpose of this letter is to ask you to chair the EGsG operational Readiness Review Team for the ST-150 Function Test station. This request involves the following expectations of the Chairman:
- Recomendation of C-ORR Team
- Developwent of C-ORR Plan
- Combret of C-ORR
- Final C-ORR Report

The above sbould be performed in accordance with the draft "Mamal Inoorporating Iessons Inarned for Kound Operational Readisiess Reviens".

The following C-ORR Charter is the document that empowers your team to perform the operational readiness review.

PURPOSE:

To assess the control measures and management systems that will assure that the sw-150 Function Test Station is being operated in a safe manner in compliance with ESEF requirenents.

C-ORR APPROVAI: The level of approval for this C-ORR will be R. E. Vallee' for EGEG Mornd.

ORBRALIIONS TO BE REVIEFED:

The C-ORR team should consider the physical, personnel, and procedural aspects of the operationis of this test station. Particular emphasis should be placed on ensuring that all operations will be performed within the approved safety envelope of the ST facility.

C-ORR TIME:

The SF-150 startup schedule calls for the C-ORR to start on Alugust 12, 1991.

DOINI OF CONISCT: The points of contact in the operations group (Component Development) are Iarsy Martin and John Hurly. 
C. N. Iindsay

Page 2

July 31, 1991

SFBCHAL RBScuRcis: Members of the review team should have some knowledge of tritivim operations and Es\& requirenents.

Please see to it that this revies is conducted in a thorough but expeditious mamner.

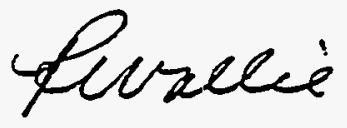

R. B. Vallee'

Associate: General Manager

RتV:ECD:CEh 
APPENDIX G 

ELEFMENIS OF AN ORR TIAN

ORR Plan

(This guidance has been taken fram Attachment 7, supplemental Directive AI 54XA, November 27, 1991.)

The ORR team Ieader is responsible for preparing the ORR Plan. The ORR Plan shall be completed such that management approvals and the DOE Area office review will be completed and the review can begin in a timely

manner. The plan shall include, at a minimm:

1. Title and approval page;

2. Introduction:

3. Objectives;

4. Scope;

5. Performance of the review; and

6. Cheaklist.

The draft ORR plan shall be reviewed, conments added, and forwarded by the appropriate manager responsible for the activity to the manager, DOE Area Office, for review. Area Office comments pertaining to the araft will be directed to the ORR team leader. Comments received from the DOE Area Office and the contractors review shall be resolved with the Area Office and or the contractor comment originators by the ORR team leader prior to issuing the ORR plan.

Title and Approval Page

The first page of the ORR plan shall contain the title of the activity being reviewed. This page should also include:

1. The name, title, and signature of the person who prepared the plan. Typically this will be the ORR team leader; and

2. A list of approvals (names, signatures, and titles) as identified in the program plan.

Introcuction

The introduction shall contain a statement that defines the reasons for performing the ORR. If applicable, a detailed discussion of the unusual conditions that lead to a cessation of operations shall be provided. This section should also provide a brief background of the purpose of the activity under review as well as a description of the physical facilities. 


\section{Objectives}

This section shall contain a list of general objectives for the ORR. These objectives should effectively sumarize the accomplishments that are detailed in the checklists.

\section{Scope}

This section shall specifically state which activity(ies) will be covered in the ORR as well as the hazard(s), as defined in the SAR, for the activity(ies). Additionally, this section shall include an identification of the necessary elements of hardware, documentation, management controls, procecurres, personnel, and programmatic functioning that will be examined.

Activities which are unioue or first-of-a-kind shall receive a review of broader scope and depth than a routine restart of an existing activity. Particular attention should be given to the interface between new activities and existing fumctions.

\section{Performance of the Revien}

This section provides details on the methodology to be used to conduct the $O R R$. The basis of a successfur $O R R$ is the deveilopment and completion of a checielist that details each iten considered essiential to a safe start-up. several methodologies may be used to develop the checklists, but the checklists shall address three major elements:

\section{Hardware;}

2. Administrative controls; and

3. Fersonnel.

Assigment of responsibilities for completion of checklist items should be detailed in this section as well as plans and schecules for reporting the results of the checklist review and follow up actions.

\section{Checirlists}

The checklist shall serve as the basis of the review. This section outlines the background information related to the checklist.

In this section of the plan, several issues colncerned with the development of the checklist shall be addressed. These issues include:
1. Methodology:
2. Major elements; and
3. Assigrment of responsibility

Checklists shall be included as an appendix to the ORR plan. 
A statement that address the methodology used to develop the checklists shall be made in this section.

There are two recoumended methods for developing the checklists; the Predeveloped Checklist Method, and the Analytical Tree Method.

Onder the predeveloped checklist method, a list of all available information related to the activity is provided by the team leader to the ORR team. The ORR team is then to decide which of the itens is needed for the systems listed in the scope of the ORR. A composite checklist for all systems or individual checklists for each system should be generated.

The ORR team may also use a "Readiness Tree" analysis of the activity as a basis for the checklist. The Management oversight and Risk Tree (MORT) type analysis is an example of an approach that may aid the ORR team in determining the details to be considered in the review.

Specific applications and guidance documents have been developed by the DOE/EG\&G Idaho, Safety System Development center (SSDC). If a readiness tree is used, then the team leader shall attach the readiness tree to the ORR plan as an appendix.

Three major elements shall be considered in each ORR and be reflected in the checklists. These elements are:

1. Hardware (Equipment \& Structures);

2. Administrative controls (Procedures); and

3. Personnel.

Examples of topics to consider for the three areas are:

Verification of hardware may involve direct cheaking of:

- Fuman factors considerations

- Building and installation to currently approved design

- Performance of enviromental qualification review

- Specific qualities checks

- Camponent and systems operation chedks

- Apparent damage

- Calibrations and maintenance

- Spare parts availability 
The related interfaces of documentation and administrative controls shall include:

- State of as-built drawings

- Corrections and compatibility of procedures

- Maintenance and calibration procedures up-to-date

- Vendor data property filed

The ORR team shall review pertinent administrative control documents such as: job plans, job planning sheets, worksheets; procecures, training plans and records, instructions for operations personnel, and other commmications used to manage the operation. This will determine if an effective administrative system exists. The team shall insure that:

1. Prescriptive documents and other instructions are correct, up-to-date, and comprehensive, and have been approved; and

2. Necessary changes have been controlled and implemented.

Op-tordate procedures shall be in place at all necessary locations. same procedures may not be collplete at the start of the ORR. The team shall review those procedures, when they become avail.able, to insure adequate completion. This later review shall be completed prior to ORR completion. The related personnel interfaces shall include:

- Personnel, trained and certified

- Personnel with demonstrated knowledge/capability concerning the operation.

All situations of nonconformance or an inability to provide verification shall be documented. When the prepared checklist does not provide sufficient detail to achieve a thorough revien, it shall be modified.

Each element of a checielist shall state the aciseptance criteria used to insure acceptance for that element. The basis of all acceptance criteria used for the ORR shall be stated.

This section shall contain a general statement on each activity indicating the types of items being reviewed, the depth of the review that is consistent with the checklist, and the acceptance criteria used for each checiclist element to determine acceptance. 